\title{
PROSVJETNA POLITIKA U SLUŽBI IDEOLOŠKOGA PRE/ODGOJA U HERCEGOVINI (1945.-1952.)
}

\author{
Marina BEUS \\ Filozofski fakultet \\ Matice hrvatske b.b. \\ $\mathrm{BiH}$ - 88000 Mostar \\ E-pošta: marina.beus@sve-mo.ba
}

\author{
UDK 37.014(497.6-3 Hercegovina)"1945/1952" \\ 316.7(497.6-3 Hercegovina)"1945/1952" \\ 37.014.523((497.6-3 Hercegovina)"1945/1952" \\ Izvorni znanstveni rad \\ Primljeno: 23. travnja 2016 \\ Prihvaćeno: 8. lipnja 2016.
}

\section{Sažetak}

Završetak rata i okončanje izbornoga procesa u studenome 1945. omogućilo je KPJ konsolidiranje političke i državne vlasti, koja je od samoga starta, iskazujući nezadovoljstvo ideološkim stanjem "narodnih masa", krenula u proces pre/odgoja, formiranjem "novog čovjeka" po vlastitoj mjeri. U tom je procesu, svakako, veoma važna karika bio obrazovni sustav koji je osim pozitivnih učinaka širenja školske mreže, opismenjavanja i organiziranja različitih izvannastavnih aktivnosti, a imajući u vidu sadržaj, metode i indoktrinirane kadrove, nesumnjivo predstavljao i najvažniju polugu u formiranju budućih "graditelja socijalističkog društva". Jedina "opozicija" unutar školskoga sustava bila je vjerska pouka kojoj su vlasti najprije namijenili sporednu ulogu proglašavajući ovaj predmet izbornim, a onda i potpuno izbacivanje iz državnoga odgojno-obrazovnog procesa. Primjenu ovakve prosvjetne politike nalazimo i u Hercegovini o čemu svjedoči veoma op- 
sežna građa Hercegovačkoga oblasnog narodnog odbora, čiji su dijelovi ugrađeni u ovaj rad.

Ključne riječi: Komunistička partija, Hercegovački oblasni/ okružni narodni odbor, Hercegovina, ideologija, obrazovanje, opismenjavanje, škola, učitelj, Crkva, vjeronauk.

\section{Uvod}

Rad je usmjeren na analizu nekih segmenata odgojno-obrazovnoga sustava koje je komunistička vlast u poslijeratnoj Jugoslaviji, a samim tim i u Hercegovini kao njezinoj sastavnici, koristila kao mehanizme u formiranju lojalne društvene zajednice. Polazeći od teze da je kulturna politika druge Jugoslavije bila instrument podrške vladajućoj nomenklaturi u radu se na temelju dosadašnje raspoložive historiografske građe i arhivskih izvora prati ideološki nadzor i rukovođenje kulturnim procesima vezanim za ovo prvo razdoblje uspostavljene države, koje je obilježeno borbom protiv nepismenosti, organiziranjem školskoga sustava, te stvaranjem institucionalne osnove za razne vidove umjetničkoga stvaralaštva. U središtu pozornosti je razvoj i funkcioniranje osnovnoškolskoga sustava na području Hercegovine, koja se dakako ne može promatrati izolirano u odnosu na državnu odnosno republičku razinu, s posebnim naglaskom na nastavne sadržaje i metode koje su vlastodršci koristili u formiranju nove, ideološki podobne generacije graditelja socijalističkoga društva. Težeći potpunoj ideološkoj kontroli školskoga sustava krenulo se u borbu protiv utjecaja vjerskih zajednica čiji je epilog bio izbacivanje vjeronauka iz škole.

\section{Proces uspostave i konsolidiranje "narodne" vlasti}

Politička konstelacija odnosa na kraju Drugoga svjetskog rata pogodovala je ideji o obnovi Jugoslavije. Iako je Vlada Kraljevine Jugoslavije boraveći u izbjeglištvu uspjela formalno pravno sačuvati svoj kontinuitet, njezin opstanak doveden je u pitanje. ${ }^{1}$ Naime, napredovanje $\mathrm{Na}$ rodnooslobodilačkoga pokreta (NOP) u ratnim operacijama na jugoslavenskom prostoru, a imajući u vidu ratne ciljeve na europskom tlu, uzdignut će NOP na razinu rasprave trojice ratnih saveznika koji su već u Teheranu 1943. dogovorili obnovu Jugoslavije, a dvije godine kasnije, na konferenciji u Jalti i uspostavu jedinstvene Privremene vlade Demo-

1 Opširnije vidjeti u: Branko Petranović (ur.), Jugoslavenske vlade u izbjeglištvu 1943-1945. Dokumenti, Arhiv Jugoslavije - Globus, Beograd - Zagreb, 1981. 
kratske Federativne Jugoslavije (DFJ). Unatoč nastojanjima Zapada da, uključivanjem i drugih političkih opcija u Privremenu vladu i Skupštinu, ograniči politički utjecaj komunista, ipak je Komunistička partija Jugoslavije (KPJ) osigurala političku premoć što joj je omogućilo neometanu provedbu svoga programa i donošenje ključnih odluka u upravljanju državom. ${ }^{2}$ Prihvaćanje i formiranje "građanske" prijelazne vlade za komuniste bio je samo kraći put ostvarenju međunarodnoga priznanja nove države. Konsolidiranje vlasti nastavljeno je izborima za Ustavotvornu skupštinu u studenom 1945., ${ }^{3}$ te proglašenjem Ustava DFJ.

Temelji državnosti šest jugoslavenskih država-članica udareni su tijekom 1944. godine kada su formirana tzv. zemaljska vijeća koja su kasnije prerasla u vlade federalnih jedinica. ${ }^{4}$ Prvi korak u tom smjeru u Bosni i Hercegovini bilo je preimenovanje ZAVNOBiH-a u Narodnu skupštinu Bosne i Hercegovine na trećem zasjedanju ovoga tijela održanom 26. travnja 1945., a dva dana kasnije tj. 28. travnja imenovana je i prva vlada

2 Zdenko Radelić, Hrvatska u Jugoslaviji 1945.-1991. Od zajedništva do razlaza, Hrvatski institut za povijest - Školska knjiga, Zagreb, 2006., str. 36, 71-72. Usp. Hrvoje Matković, Povijest Jugoslavije (1918-1991). Hrvatski pogled, P. I. P. Pavičić, Zagreb, 1998., str. 258-268; DušAN BILANDžIĆ, Hrvatska moderna povijest, Golden marketing, Zagreb, 1999., str. 171.

3 Zahvaljujući represivnim mjerama i zakonodavnim aktima posebice Zakonu o izboru narodnih poslanika i Zakonu o biračkim spiskovima komunisti su osigurali potpunu vlast. Naime, od 524 izabrana člana Narodne skupštine FNRJ na izborima 1945. godine njih 404 bili su članovi KPJ što znači 77 \%, dok u republičkim skupštinama od ukupno 1062 člana njih 892 bili su komunisti, odnosno 84 \%. Usp. Z. RAdelić, Hrvatska u Jugoslaviji 1945.-1991..., str. 72-73, 77-78. O ograničenju izbornoga prava Zakonom o biračkim spiskovima vidjeti u: KATARINA SPEHNJAK, Javnost i propaganda. Narodna fronta u politici i kulturi Hrvatske 1945.-1952., Hrvatski institut za povijest - Dom i svijet, Zagreb, 2002., str. 128 (bilj. br. 176). Vlada NR BiH Uredbu o provođenju članka 4 navedenog Zakona kojim se oduzima biračko pravo pojedincima i skupinama, donijela je na svojoj sjednici od 17. kolovoza 1945. Usp. Rosa Cvijović (prir.), Narodna Vlada Narodne Republike Bosne i Hercegovine 1945.-1948. Zapisnici, Arhiv Bosne i Hercegovine, Sarajevo, 1985., str. 25, 27.

4 Iako je uobičajeno da se dvije ili više država-članica udružuje u zajedničku državu, ovdje je bio obrnuti redoslijed. Naime, na Drugom zasjedanju Antifašističkoga vijeća narodnog oslobođenja Jugoslavije (AVNOJ-a), 29. studenoga 1943., konstituirana je, odnosno obnovljena Jugoslavija, a tek sljedeće godine došlo je do konstituiranja njezinih država-članica. O drugom zasjedanju AVNOJ-a i odlukama vidjeti u: Vladimir Dedier, Dokumenti 1948., I., Rad, Beograd, 1979. , str. 7-20. O konstituiranju i funkcioniranju ZAVNOBiH-a vidjeti u: Vera KaTZ, Društveni i ekonomski razvoj Bosne i Hercegovine 1945.-1953., Institut za istoriju, Sarajevo, 2011., str. 78-106, 124-130. 
NR Bosne i Hercegovine, ${ }^{5}$ koja je svoj rad temeljila na Deklaraciji ZAVNOBiH-a, obvezujući se kako će "čuvati i učvršćivati tekovine [njegove] oružane borbe... čuvati iznad svega ravnopravnost, bratstvo i jedinstvo Srba, muslimana i Hrvata, doprinoseći sa svoje strane sve za učvršćenje bratstva svih naroda Jugoslavije, čijim je zajedničkim naporima i žrtvama stvorena ravnopravna i bratska zajednica naroda - demokratska federativna Jugoslavija". ${ }^{6}$ Proces stvaranja zakonodavnoga okvira vlasti završen je proglašenjem Ustava NR BiH u siječnju $1947 .^{7}$

Jedan od prvih poteza "narodne vlasti" još tijekom zasjedanja Predsjedništva ZAVNOBiH-a u prosincu 1944. bio je administrativno-teritorijalna reorganizacija $\mathrm{BiH}$ koju je pripremala posebno formirana Komisija pri ZAVNOBiH-u. Unatoč brojnim inačicama kada je riječ o administrativno-teritorijalnom reorganiziranju poslijeratne Bosne $\mathrm{i}$ Hercegovine, do 1952. godine, Hercegovina je uglavnom činila jednu teritorijalnu cjelinu. Ovaj poseban status Hercegovine očitovan već u zavnobihovskoj odluci kada je Bosna i Hercegovina podijeljena na pet okruga i oblast Hercegovinu s jedanaest kotareva, proizlazio je u prvom redu iz svjesnosti vlasti o dubokoj međunacionalnoj netrpeljivosti i podijeljenosti koja je trebala iščeznuti kako su tvrdili "na temelju bratstva stvorenog u (našoj) zajedničkoj narodno-oslobodilačkoj borbi". ${ }^{8}$ Naravno s učvršćivanjem vlasti slijedile su nove reorganizacije, koje su sa sobom nosile ne samo preimenovanja nego i izmjene razgraničenja kotareva i mjesnih područja s ciljem razbijanja jednonacionalne strukture stanovništva i stvaranja preduvjeta za nesmetan partijski utjecaj na oblikovanje i kontrolu javnoga mijenja i društvenih odnosa. ${ }^{9}$ Budući

5 Hamdija Ćemerlić, "Prva Vlada narodne Republike Bosne i Hercegovine", u: Rosa Cvijović (prir.), Narodna Vlada Narodne Republike Bosne i Hercegovine 1945.-1948. Zapisnici, Arhiv Bosne i Hercegovine, Sarajevo, 1985., str. III. Zakon Narodne skupštine Bosne i Hercegovine o Narodnoj Vladi Bosne i Hercegovine i Ukaz o imenovanju Narodne vlade Bosne i Hercegovine u: R. Cvijović (prir.), Narodna Vlada Narodne Republike Bosne i Hercegovine 1945.-1948. Zapisnici, str. 1-3.

6 R. Cvijović (prir.), Narodna Vlada Narodne Republike Bosne i Hercegovine 1945.1948. Zapisnici, str. 10.

7 "Ustav Narodne Republike Bosne i Hercegovine", u: Službeni list NR BiH, Sarajevo, 1/1947., str. 1-18.

8 Vera Katz, "Nekoliko primjera ideološke upotrebe 'narodnog prosvjećivanja' u Hercegovini 1945.-1952.", u: Ivica Lučić (ur.), Hum i Hercegovina kroz povijest. Zbornik radova s međunarodnoga znanstvenog skupa održanog u Mostaru 5. i 6. studenoga 2009., II., Hrvatski institut za povijest, Zagreb, 2011., str. 513.

9 Detaljnije o administrativno-teritorijalnoj organizaciji $\mathrm{BiH}$ u navedenom razdoblju vidjeti u: V. Katz, Društveni i ekonomski razvoj Bosne i Hercegovine 1945.-1953., 
da je ključna uloga u kreiranju društvene zbilje u totalitarnom sustavu uvijek u rukama vladajuće elite, tako je i u ovom slučaju cjelokupna politička moć bila koncentrirana u rukama Centralnoga komiteta (CK) KPJ, odnosno njegova najužeg tijela Politbiroa predvođenog Josipom Brozom. Naravno, jedinstvo političke i državne vlasti počevši od savezne razine do najnižih lokalnih tijela vlasti garantiralo je neupitnost $\mathrm{u}$ provedbi zacrtanih političkih ciljeva proizišlih iz revolucionarnih težnji u izgradnji socijalističkoga društvenog poretka.

\section{Kulturna politika u funkciji izgradnje jugoslavenskoga socijalizma}

\subsection{Narodno prosvjećivanje}

Kulturna politika kao dio društvene zbilje neraskidivo je povezana $s$ društvenim, ekonomskim i političkim odnosima određene države, odnosno s kulturom vladajućih elita koje svoj model nude, ili pak, kakav je slučaj u totalitarnim sustavima, nameću široj društvenoj zajednici kroz različite kulturne i prosvjetne institucije s krajnjim ciljem formiranja novoga čovjeka po vlastitoj mjeri. Polazeći s ovakvoga stajališta i CK KPJ preko svoga Odjeljenja za agitaciju i propagandu (Agitprop) ${ }^{10}$ krenuo je u izgradnju nove kulture koja je trebala biti podloga stvaranju zacrtanoga društvenog uređenja utemeljenoga, kako se propagiralo, na vladavini "radnoga naroda". Očito nezadovoljan ideološkim stanjem "radnih narodnih masa" CK KPJ već je u ožujku 1945. donio direktivu $O$ reorganizaciji agitpropa i propagande prema kojoj je cjelokupni

str. 107-113, 130-147, 151-156. Usp. V. KATz, "Nekoliko primjera ideološke upotrebe 'narodnog prosvjećivanja' u Hercegovini 1945.-1952.", str. 509-516. O administrativnom statusu Hercegovine u navedenom razdoblju vidjeti u: Adnan Velagić, "Administrativno uređenje Hercegovine od 1945. do 1952. godine", u: Most. Časopis za obrazovanje, nauku i kulturu, 191 (102), Mostar, 2005., str. 82-84.

10 Odjeljenje za agitaciju i propagandu (Agitprop) formirano je u Drugome svjetskom ratu, a njegova zadaća bila je kontrola i usmjeravanje cjelokupnoga kulturnog stvaralaštva u državi prema ideološko-političkim direktivama CK KPJ. U radu se oslanjao na masovne organizacije (Narodnu frontu - NF, sindikate, Antifašističku frontu žena - AFŽ, omladinske organizacije), ministarstva kulture, znanosti i prosvjete. Reorganiziran je sukladno direktivi CK KPJ u proljeće 1945. Opširnije o fazama, ustrojstvu i djelovanju Agitpropa vidjeti u: BRANKO Petranović, Istorija Jugoslavije. Socijalistička Jugoslavija 1945-1988., III., Neolit, Beograd, str. 120-126; LuubodRAg Dimić, Agitprop kultura. Agitpropovska faza kulturne politike u Srbiji 1945-1952., IRO "Rad", Beograd, 1988., str. 36. Shema organizacijske strukture prikazana u: Branka Doknić - Milić F. Petrović - Ivan Hofman (prir.), Kulturna politika Jugoslavije 1945-1952. Zbornik dokumenata, I., Arhiv Jugoslavije, 2009., str. 101-102. 
agitacijski, propagandni i kulturno-prosvjetni rad organiziran pod pokroviteljstvom partijskih struktura, pa je u tom smislu naloženo da se "uz sve partijske komitete - centralne, pokrajinske, oblasne, okružne, mesne, sreske, rejonske i u većim gradovima (Beograd, Skoplje, Zagreb, Subotica, Sarajevo, Novi Sad, Ljubljana, Split, a po potrebi i drugima) stvor[iti]e agitacijsko-propagandne komisije. ${ }^{11}$ Naravno, prema navedenom naputku komisije za agitaciju i propagandu formirane su i pri Pokrajinskom komitetu KPJ za $\mathrm{BiH},{ }^{12}$ te svim okružnim komitetima, pa tako i hercegovačkom. ${ }^{13}$ Polazeći od Lenjinovih ideja da se stari sustavi ne mogu nadići "nikakvim političkim preobražajem (...) već jedino podizanjem kulture", komisije agitpropa su, preko tzv. masovnih organizacija (NF, AFŽ-a, omladinskih organizacija), preuzele ključnu ulogu u provođenju "kulturne revolucije". ${ }^{4}$ Najvažniji cilj kojega su vlastodršci na kulturnom planu postavili bilo je "narodno prosvjećivanje" koje je podrazumijevalo ne samo rješavanje pitanja kulturne zaostalosti, nego širenjem mreže kulturnih institucija i kruga korisnika ${ }^{15}$ eliminirati ostatke ideološke oporbe i omogućiti pre/odgoj u socijalističkom duhu, a potom i razvijati svijest o značenju i prednostima socijalističkoga sustava. Naravno, politika prosvjećivanja, kao jedan od ideoloških instrumenata državno-političkoga aparata, imala je veoma važnu ulogu

11 "Uputstvo o reorganizaciji aparata agitacije i propagande", u: B. Doknić - M. F. Petrović - I. Hofman (prir.), Kulturna politika Jugoslavije 1945-1952. Zbornik dokumenata, I., dok. br. 1, str. 118.

12 Naime do 1948. godine u Bosni i Hercegovini KPJ organizacijski je djelovala preko Pokrajinskoga komiteta (PK) za BiH. Prema naputku CK KPJ već od srpnja 1945. vodeću ulogu u PK za BiH imao je Politbiro na čelu sa sekretarom Đurom Pucarom Starim, a za organizacijskoga sekretara izabran je Cvijetin Mijatović. Ostali članovi Politbiroa bili su: Hasan Brkić, Rodoljub Čolaković, Uglješa Danilović, Avdo Humo i Rudi Kolak. Usp. Husnija Kamberović, Hod po trnju. Iz bosanskohercegovačke historije 20. stoljeća, Institut za istoriju, Sarajevo, 2011., str. 124; Drago BorovČAnIN, "KPJ u BiH u periodu obnove i početnim fazama planske izgradnje 1945.-1948.", u: Istorija saveza komunista BiH, II., Institut za istoriju, Sarajevo, 1990., str. 23.

13 V. Katz, Društveni i ekonomski razvoj Bosne i Hercegovine 1945.-1953., str. 180-181.

14 Branka Doknić, "Kulturna politika Jugoslavije 1845-1952", u: B. Doknić - M. F. Petrović - I. Hofman (prir.), Kulturna politika Jugoslavije 1945-1952. Zbornik dokumenata, I., str. 16.

15 U prvom razdoblju posebno ciljana skupina bilo je seosko stanovništvo kojega se kroz obrazovanje i kulturnu preobrazbu nastojalo integrirati u postojeći društveni sustav. Usp. Arhiv HercegovačKo-neretvanske Županije/Kantona (dalje: AHNŽ/K), HercegovaČKi oblasni nAROdNi odbor - ODJEL PROSVJETE (dalje: HONO OP), Dopis Ministarstva prosvjete narodne vlade BiH upućen Oblasnom narodnom odboru Mostar, kut. 500-2000/1945., br. 1178/45., str. 1. 
kako u obnovi razrušene zemlje, tako i u gospodarskom oporavku, posebice nakon prelaska na planski privredni razvoj, jer kako je isticano "ekonomska izgradnja [naše] zemlje zahtijeva visoko obrazovanoga kulturnog čovjeka, a s druge strane baš ta široka kulturnost dalje utječe i ubrzava ekonomsku izgradnju [naše] domovine", što bi vodilo "višem" cilju izgradnje socijalizma kojega je trebalo "stvarati [socijalizam] u svijesti ljudi". ${ }^{16}$

Jedan od veoma važnih segmenata prosvjećivanja bilo je smanjivanje i suzbijanje nepismenosti. Iako je ovaj proces započeo još tijekom ratnih zbivanja organiziranjem tečajeva za opismenjavanje u partizanskim jedinicama i na "oslobođenom" području, prema prikupljenim podatcima sredinom 1945. godine u BiH je bilo oko 952.000 odraslih nepismenih osoba ili $72 \%$, od čega je oko 250.000 prešlo dobnu granicu iznad 45 godina. ${ }^{17}$ Najveći postotak nepismenih odnosio se na seosko stanovništvo ${ }^{18}$ i radništvo. Na ovaj problem ukazao je i Cvijetin Mijatović, ministar prosvjete NR BiH na konferenciji o narodnom prosvjećivanju održanoj u Sarajevu 1. i 2. listopada 1945., ističući kako težište prosvjetnoga rada moraju biti radnici i seljaci. Očito želeći uozbiljiti ovaj proces poslužio se starom partijskom parolom o "neprijatelju koji nikada ne spava", upozoravajući aktiviste na terenu kako još uvijek postoje "izvjesni dijelovi hrvatskog seljaštva koji pod utjecajem reakcionarnog dijela katoličkog klera nije pokazao dovoljno inicijative odozdo, a isto tako postoji dio konzervativnih muslimanskih i srpskih masa koji pod raznim reakcionarnim utjecajem ne uviđaju značaj prosvjećenosti i ne pokazuju dovoljno interesa da savladaju neukost i nepismenost". Mija-

16 Četvrta konferencija Narodne fronte grada Zagreba, Gradski odbor narodnog fronta Zagreb, 1948., str. 23. Usp. K. SPEHnJAK, Javnost i propaganda. Narodna fronta u politici i kulturi Hrvatske 1945.-1952., str. 165. Petogodišnjim planom predviđeno je završavanje procesa opismenjavanja i obvezno osnovno školovanje za svu djecu školskoga uzrasta, što je podrazumijevalo i nove investicije, pa je tako u razdoblju od 1947.-1951. godine planirana izgradnja 4130 novih škola s 320.000 učeničkih mjesta. Opširnije o ovoj problematici u: Vladimir Pešść, "Obavezno osnovno školovanje u petogodišnjem planu", u: Savremena škola. Časopis za pedagoška pitanja, Beograd, 4-5/1947., str. 11-21.

17 Arhiv Bosne i Hercegovine (dalje: ABiH), Savjet za prosvjetu, Nauku i KUlturu NR BIH (dalje: SPNK NRBiH), Kulturno-prosvjetni rad u Bosni i Hercegovini od oslobođenja do danas, kut. 17, br. 611/51., str. 2.

18 Prema podatcima iz 1939. godine u $\mathrm{BiH}$ nepismeno je bilo oko $90 \%$ seoskoga stanovništva. Od ukupnoga broja stanovnika pismenih je bilo samo 27,1\%. Ako se sagleda spolna struktura, dolazi se do podatka da je čak 87,65 \% žena u odnosu na njihov ukupni broj bilo nepismeno. Usp. ABiH, SPNK NR BiH, Kulturno-prosvjetni rad u Bosni i Hercegovini od oslobođenja do danas, kut. 17, br. 611/51., str. 2; V. KATZ, Društveni i ekonomski razvoj Bosne i Hercegovine 1945.-1953., str. 53. 
tović je također, upozorio i na "razne neprijateljske utjecaje na radničku klasu", koji se, prema njegovu viđenju, moraju i mogu otkloniti procesom narodnoga prosvjećivanja. ${ }^{19}$ Program rada na narodnom prosvjećivanju osmišljen u samome državno-partijskom vrhu u obliku naputaka prenosio se do prosvjetnih odjela najnižih lokalnih razina koji su bili zaduženi za animiranje i angažiranje svih društvenih slojeva. ${ }^{20}$ Držeći kako nepismen čovjek nije samo "neprijatelj prosvjete" nego i "političkog i društvenog života", jer "nepismen čovjek stoji izvan politike", započela je široka kampanja opismenjavanja odraslih. Stručno vođenje analfabetskih tečajeva povjereno je učiteljima, ali i nestručnim poučavateljima, uglavnom partijskim aktivistima, koji su prije postupka opismenjavanja prolazili kratki tečaj iz metodike opismenjavanja. Tečajevi su organizirani uglavnom u zimskom razdoblju u večernjim satima. $U$ cilju povezivanja pismenosti i općega obrazovanja organizirani su i tečajevi općih znanja namijenjeni omladini iznad 14 godina koji su trebali produbiti i upoznati mlade s "istorijom narodnooslobodilačke borbe i njenim tekovinama", te tečajevi za produženo obrazovanje ${ }^{21}$ i stručni tečajevi. Nažalost, pošast nepismenosti nije zaobišla ni hercegovačko područje pa Hercegovački okružni narodni odbor u svome tromjesečnom izvješću iz svibnja 1946. godine bilježi, iako prema nepotpunim podatcima, 42.274 nepismene osobe. Najveći postotak činile su žene, njih 34.999 ili $83 \%$. Broj nepismenih muškaraca bio je znatno manji i iznosio je 7275. ${ }^{22}$ Unatoč teškim uvjetima rada zbog ratnog pustošenja u kojem su stradale mnoge škole, ${ }^{23}$ te nedostatka školskoga inventara, priručnika i pisaćeg pribora, i na hercegovačkome području proces opismenjavanja i kulturno-prosvjetne preobrazbe stanovništva, prema izvješćima s tere-

$19 \mathrm{ABiH}$, Ministarstvo prosvjete NR BiH (dalje: MP NR BiH), Zapisnik s Konferencije po pitanju narodnoga prosvjećivanja, kut. 193, br. 24/1945., str. 2.

20 Navodim samo neke od dokumenata: AHNŽ/K, HONO OP, Dopis Ministarstva prosvjete narodne vlade $\mathrm{BiH}$ upućen Oblasnom narodnom odboru Mostar, kut. 500-2000/1945., br. 1178/45., str. 1-6; AHNŽ/K, HONO OP, Potrebne pripreme za prosvetni rad u toku jesensko-zimske sezone, kut. 2000-3000, br. 2366/45., str. 1-3; AHNŽ/K, HONO OP, Plan zimske kampanje, kut. 7000-8500/1946., br. 7428/46., str. 1-3.

21 Na ovim tečajevima stjecala su se u skraćenom vremenu i opsegu znanja nižih srednjih škola, odnosno bili su "izvor" novih kadrova za prosvjetni rad na terenu. Usp. AHNŽ/K, HONO OP, Dopis Ministarstva prosvjete narodne vlade BiH upućen Oblasnom narodnom odboru Mostar, kut. 500-2000/1945., br. 1178/45., str. 3.

22 HeRCEGOVAČKI OKRUŽNI NARODNI ODBOR, Izvještaj o radu Izvršnog odbora u razdoblju od 20. februara 1946. god. do 26. maja 1946. godine, Štamparija "Sloboda", Mostar, 1946., str. 84.

23 O ovoj problematici detaljnije će biti riječi na narednim stranicama ovoga rada. 
na, bilježio je svoje uspjehe. Kampanja opismenjavanja, kao i u ostalim dijelovima $\mathrm{BiH}$, započinjala je manifestacijom "Nedjelje narodnog prosvjećivanja" tijekom koje je, preko tiska, te različitih vidova okupljanja i promotivnih plakata, vršena promidžba i animacija stanovništva. Također, u ovoj promotivnoj "nedjelji" prodajom promidžbenoga materijala nastojalo se prikupiti i dio novčanih sredstava, te pisaćih potrepština za organiziranje tečajeva i drugih aktivnosti na kulturno-prosvjetnom planu. ${ }^{24}$ Već u prvoj kampanji u hercegovačkome okrugu organiziran je 591 tečaj koji je pohađalo 13.749 polaznika. ${ }^{25}$ Sudeći prema zabilješkama s terena među polaznicima prednjačile su žene različite starosne dobi (od 15 do 55 godina). ${ }^{26}$ Razlog tomu možemo tražiti s jedne strane $u$ već navedenom visokom postotku nepismenosti žena, ali i u činjenici da je riječ o ciljanoj skupini u sklopu politike narodnoga prosvjećivanja, očekujući, nakon stečenoga osnovnog znanja i obrazovanja, njihov bespoštedan angažman u društveno-političkome životu svoje sredine. Međutim, učinak barem tijekom 1945. i 1946. godine nije bio zadovoljavajući. ${ }^{27}$ Iz izvještaja koja su pristizala u Oblasni odnosno Okružni narodni odbor lokalna tijela upozoravala su ne samo na nedostatak materijalnih sredstava, nego i na neiskustva "omladinaca volontera" koji su uz učitelje održavali tečajeve, te nedovoljnu angažiranost partijskih aktivista. Imajući u vidu i činjenicu da je proces opismenjavanja bio usmjeren u prvom redu na radništvo i seosko stanovništvo, odustajanju velikoga broja polaznika znatno je doprinijela i činjenica da se s tečajevima u prve dvije godine krenulo u kasnom zimskom razdoblju, pa se njihovo završavanje poklopilo s proljetnim poljoprivrednim radovima. ${ }^{28}$ Kako bi se izbjegao ovaj problem, četveromjesečna zimska kampanja opismenjavanja sljedećih godina trajala je od početka studenoga

$24 \mathrm{ABiH}, \mathrm{SPNK}$ NR BiH, Kulturno-prosvjetni rad u Bosni i Hercegovini od oslobođenja do danas, kut. 17, br. 611/51., str. 2.

25 HERCEGOVAČKI OKRUŽNI NARODNI ODBOR, Izvještaj o radu Izvršnog odbora..., str. 85.

26 AHNŽ/K, HONO OP, Gradski narodni odbor u Mostaru. Izvještaj prosvjetnog rada u toku mjeseca aprila, od 30. 4. 1946., kut. 1200-1800/1946., br. 2463/46., str. 3.

27 Prema podatcima do svibnja 1946. završeno je 340 tečajeva na kojima su opismenjene 6094 osobe. Usp. HERCEGOVAČKI OKRUŽNI NARODNI ODBOR, Izvještajo radu Izvršnog odbora..., str. 85.

28 Isto; AHNŽ/K, HONO OP, Gradski narodni odbor u Mostaru - Izvještaj prosvjetnog rada u toku mjeseca aprila, od 30. 4. 1946., kut. 1200-1800/1946., br. 2463/46., str. 3; AHNŽ/K, HONO OP, Sreski narodni odbor u Gacku - Mjesečni izvještaj o prosvjetnom radu, kut. 500-2000/1945., br. 1178/45., str. 1; Sreski narodni odbor Bileća - Mjesečni izvještaj o prosvjetnom radu, kut. 500-2000/1945., br. 1178/45., str. 1 . 
do početka ožujka, ${ }^{29}$ a s ciljem podizanja kvalitete tečajeva potican je i natjecateljski duh ne samo među polaznicima jedne tečajne grupe, nego i između pojedinih mjesnih odbora. ${ }^{30}$ Ovako organiziran rad rezultirao je svakako pozitivnim učincima. Prema arhivskim dokumentima u razdoblju od 1945. do 1951. godine u BiH održano je 44.072 tečaja na kojima je opismenjeno 709.437 osoba. Među opismenjenim bilo je 256.223 muškaraca i 453.214 žena, a sagledavajući dobnu strukturu valja naglasiti da je njih 508.034 bilo mlađe od 25 godina starosti, dok su preostale 201.403 opismenjene osobe bile iznad 25 godina starosti. ${ }^{31}$ Unatoč ovim impresivnim brojkama treba napomenuti da podatak, iz svibnja 1951. koji ovaj dokument donosi, o preostale 215.563 nepismene osobe ne može biti vjerodostojan budući da su vlasti u ovim izračunima kao početni parametar uzimale podatak iz 1945. godine, kada je prema njihovoj evidenciji, na bosansko-hercegovačkom području zabilježeno 952.000 odraslih nepismenih osoba, istovremeno zanemarujući činjenicu da mnogobrojna djeca iz godine u godinu nisu polazila u školu što je zasigurno mijenjalo ovu početnu sliku na terenu. Ovo potvrđuju i podatci popisa iz 1953. godine, kada je evidentirano 853.151 nepismena osoba starija od 10 godina, ${ }^{32}$ što stavlja pod upit vjerodostojnost početnih pokazatelja i otvara pitanje politiziranja ove problematike, o čemu svjedoče i izjave partijskoga vrha priznajući da su analfabetski tečajevi "bili više trka za ciframa, nego što je stvarno ljudi opismenjeno".33

Veoma važnu ulogu na kulturno-prosvjetnom unaprjeđenju posebice seoskoga stanovništva imale su knjižnice i čitaonice. Popularizaciji knjige posebice $u$ manjim seoskim sredinama trebale su pridonijeti pokretne knjižnice. Zahvaljujući Ministarstvu prosvjete u Hercegovini je,

29 AHNŽ/K, HONO OP, Plan zimske kampanje, kut. 7000-8500/1946., br. 7428/46., str. 1.

30 Primjerice mjesni odbori natjecali su se tko će prije iz svoga djelokruga potpuno opismeniti stanovništvo do 45 starosti, zatim tko će organizirati veći broj čitalačkih grupa, pripremiti veći broj dopisa za tisak, izdati više zidnih novina itd. Usp. AHNŽ/K, Privremeni oblasni narodni odbor Mostar (dalje: PONOM), Sresko savjetovanje o nar.[odnom] prosvjećivanju, kut. 3000-4000/1949., br. 3010/49., str. 2.

$31 \mathrm{ABiH}$, SPNK NR BiH, Kulturno-prosvjetni rad u Bosni i Hercegovini od oslobođenja do danas, kut. 17, br. 611/51., str. 2.

32 Usp. Dragiša Ivković, Školstvo u Bosni i Hercegovini, NIP "Zadrugar", Sarajevo, 1963., str. 23.

33 Ivana Dobrivojević, "Od ruralnog kao urbanom. Modernizacija Republike Bosne i Hercegovine u FNRJ 1945-1955.", u: Husnija Kamberović (ur.), Identiteti Bosne i Hercegovine kroz historiju. Zbornik radova, II., Institut za istoriju, Sarajevo, 2011., str. 14-15. 
već u prvoj polovici 1946. godine, bilo 60 pokretnih knjižnica, te 126 omladinskih knjižnica koje su raspolagale fondom od $10.500 \mathrm{knjiga}$. Također, Zemaljska biblioteka iz Sarajeva imala je svoje filijale u svim sreskim središtima i u Mostaru čiji je početni fond od 800 knjiga redovito dopunjavan. ${ }^{34}$ Međutim, veći broj otvorenih knjižnica, posebice seoskih koje su u biti bile "gomil[u]a knjiga strpanih bez ikakvog reda u neki orman škole, narodnog odbora ili seoske zadruge", nisu služile svojoj svrsi jer je potražnja za knjigom bila veoma mala. ${ }^{35}$

Naravno, svoje mjesto u kulturno-odgojnom procesu našli su i prosvjetni domovi ili kako su ih u gradovima nazivali domovi kulture, ${ }^{36}$ koji su predstavljali središta redovitih okupljanja gdje su organizirane razne priredbe "nobovske" tematike, predavanja u organizaciji narodnih sveučilišta, stalne izložbe, usmene novine pa i rad čitalačkih grupa na kojima su sudionicima prezentirani i tumačeni sadržaji dnevnih tiskovina poput Sarajevskog dnevnika, Borbe i Seljačke borbe, što je omogućavalo jedan spoj u kulturno-prosvjetnoj, ideološko-političkoj i društveno-moralnoj izgradnji stanovništva. ${ }^{37}$ Ovomu procesu dodatni "vjetar u leđa" trebala

34 HeRCEgOVAČKI OKRUŽNI NARODNI ODBOR, Izvještaj o radu Izvršnog odbora..., str. 86. Literatura je bila naravno, pod budnim okom vlasti, odnosno očišćena od "petparačke literature" i u službi "njihovih" novih izdanja. Usp. AHNŽ/K, HONO OP, Dopis Ministarstva prosvjete narodne vlade $\mathrm{BiH}$ upućen Oblasnom narodnom odboru Mostar, kut. 500-2000/1945., br. 1178/45., str. 4-5; AHNŽ/K, HONO OP, Potrebne pripreme za prosvetni rad u toku jesensko-zimske sezone, kut. 20003000/1945., br. 2366/45., str. 2-3; AHNŽ/K, HONO OP, Plan zimske kampanje, kut. 7000-8300/1946., br. 7428/46., str. 2. Prema podatcima iz 1950. godine na teritoriju BiH djelovalo je 795 knjižnica i čitaonica, a kao rezultat vođene politike "približiti selo gradu" čak 479 knjižnica bilo je na selu dok je preostalih 316 djelovalo u gradskim područjima. Knjižni fond iznosio je 393.093 knjige. Usp. ABiH, SPNK NR BiH, Kulturno-prosvjetni rad u Bosni i Hercegovini od oslobođenja do danas, kut. 17, br. 611/51., str. 6.

35 I. Dobrivojević, "Od ruralnog kao urbanom. Modernizacija Republike Bosne i Hercegovine u FNRJ 1945-1955.", str. 15.

36 Za potrebe izgradnje ondašnjega Doma kulture u Mostaru Mostarsko-duvanjskoj biskupiji "narodna vlast" oduzela je ne samo zemljište zvano Kajtazovina, nego i građevinski materijal pripravljen za izgradnju mostarske katedrale. Usp. ABiH, Komisija Za vJersKa PITANJA (dalje: KVP), II požurnica za davanje mišljenja o eksproprijaciji crkve i zemljišta u Foči i Mostaru, kut. 3, br. 222/54., str. 1; ABiH, KVP, Dopis upućen Predsjedniku Izvršnog vijeća S. R. Bosne i Hercegovine - prijepis, kut. 39, br. 37/66., str. 3; ABiH, KVP, Komisiji za vjerska pitanja Narodne skupštine sreza Mostar - prijepis bez naslova, kut. 22, br. 76/64., str. 2.

37 HercegovaČKi OKRUŽNi NARODNI OdBOR, Izvještaj o radu Izvršnog odbora..., str. 85-86; Milić F. Petrović, "Polazne osnove za kulturno-prosvetni rad", u: B. Doknić - M. F. Petrović - I. Hofman (prir.), Kulturna politika Jugoslavije 19451952. Zbornik dokumenata, I., str. 63-64. 
je dati filmska i radio produkcija koja je bila pod budnim okom vlasti. ${ }^{38}$ U nedostatku domaćih filmskih sadržaja, ${ }^{39}$ naravno zabranjujući predratnu produkciju, pristupilo se, preko Državnoga filmskog poduzeća Jugoslavije (DFPJ) strogo cenzuriranom uvozu, u prvom redu, "dobrih" sovjetskih filmova koji su pod budnim okom agitpropa trebali doprijeti ne samo u gradska područja nego i u radnička središta i sela. ${ }^{40} \mathrm{Da}$ se ova praksa primjenjivala i u Hercegovini potvrđuje izvješće duvanjskoga narodnog odbora iz kojega se može zaključiti kako je riječ o pomno biranoj produkciji filmova poput "Obrana Moskve" i "Oslobođenje Čehoslovačke", na čiju su gledanost narodne vlasti budno pazile. ${ }^{41}$ Općem narodnom prosvjećivanju trebala je pridonijeti i pokrenuta emisija na Radio Beogradu koja je emitirana, ne slučajno, nedjeljom u terminu od 11 do 12 sati u sklopu koje su obrađivane razne teme društveno-političkoga karaktera ili pak emisije iz privredne domene emitirane svakoga dana u večernjim satima. Zbog maloga broja radio-prijemnika mjesni narodni odbori, uz pomoć učitelja i drugih javnih djelatnika, imali su obvezu u domovima kulture i sličnim ustanovama organizirati zajedničko slušanje i tumačenja među najširim slojevima pučanstva, što je svakako doprinosilo formiranju javnoga mnijenja. ${ }^{42}$ Dakle, ne zanemarujući pozitivne nakane i učinke vlasti kako na području opismenjavanja tako i kulturnoga oplemenjivanja stanovništva, ipak, ne može se zanemariti činjenica da su svi ovi potezi u pozadini bili u službi izgradnje ideološki unificiranoga društva koje je imalo zadatak poduprijeti politički sustav na kojemu je ta ista vlast počivala.

38 Usp. Milovan Đilas, "O prosvjetnom, kulturnom i naučnom razvitku u našoj zemlji", u: Savremena škola. Časopis za pedagoška pitanja, Beograd, 1/1947., str. 4-5.

39 Prvi jugoslavenski poslijeratni film Slavica, "nobovske" tematike bio je prikazan u svibnju 1947., a već sljedeće godine snimljeni su i Živjet će ovaj narod i Barba Žvane, a onda i Bakonja fra Brne, Svoga tijela gospodar itd., što je filmsku produkciju učinilo dostupnom i nepismenim gledateljima. Usp. B. Petranović, Istorija Jugoslavije. Socijalistička Jugoslavija 1945-1988., III., str. 142-143.

40 Isto, str. 140.

41 Navedeni filmovi u službi narodnoga prosvjećivanja bili su na repertoaru od 2. prosinca do 5. prosinca 1946. u kinima u Duvnu, Brišniku i Grabovici, a redovito je vođena i evidencija o broju kino-posjetitelja. AHNŽ/K, HONO OP, Izvještaj o radu na narodnom prosvjećivanju za mjesec decembar 1946., kut. 1-1000/1947., br. 597/47., str. 1 .

42 AHNŽ/K, HONO OP, Radio-emisije za narodno prosvjećivanje, kut. 5002000/1945., br. 989/45., str. 1-2. 


\section{2. Škola u službi ideološkoga pre/odgoja}

\subsubsection{Zakonske regulative osnovnoškolskoga obrazovanja}

Komunisti su već s preuzimanjem vlasti u obrazovnom sustavu vidjeli veoma važan ideološki aparat u konsolidiranju jugoslavenskoga socijalističkog poretka. Koristeći se školskim sustavom kao ključnim posrednikom $\mathrm{u}$ interpretiranju društvene zbilje usađivanje praktičnoga znanja usko je povezivano s propagiranjem i nametanjem vladajuće ideologije. ${ }^{43}$ Stoga je velika pozornost posvećivana ne samo podizanju razgranate školske mreže nego i kadrovskoj politici. Organizacijski ustroj predškolskoga, osnovnoškolskoga i srednjoškolskoga odgoja i obrazovanja formiranjem Narodne vlade $\mathrm{BiH}$ povjeren je Ministarstvu prosvjete odnosno od 1951. godine Savjetu za prosvjetu, znanost i kulturu, ${ }^{44}$ dok su stručne škole bile u djelokrugu odgovarajućih strukovnih ministarstava. $\mathrm{U}$ organizacijskom smislu najveće promjene $\mathrm{u}$ poslijeratnom razdoblju pretrpjelo je osnovno školstvo. Naime, nova država naslijedila je prijeratnu shemu općega obrazovanja prema kojoj su postojala tri osnovna tipa općeobrazovnih škola, svaki u trajanju od četiri godine: osnovne škole koje su uključivale djecu od 7. godine života, niže gimnazije, koje su trajale do 15 . godine života, te više gimnazije koje su završavale polaganje maturalnoga ispita. ${ }^{45}$ Međutim, nedostatak obrazovanoga kadra, posebice ako se ima u vidu stvaranje preduvjeta za prelazak na plansku privredu, tražio je jedan ubrzaniji sustav školovanja, pa je stoga Vlada DFJ rješenje pronašla već u listopadu 1945. proklamirajući Zakon o obaveznim sedmogodišnjim školama koje su objedinjavale četverogodišnju osnovnu školu i tri razreda niže gimnazije. ${ }^{46}$ Specifičnost uvjeta u kojima su funkcionirale pojedine republike omogućavala je mjerodavnim ministarstvima detaljnije razrade i prila-

43 MARко FuČEK, "Konsolidacija jugoslavenskoga socijalizma kroz ideološke aparate države", u: Časopis za suvremenu povijest, Zagreb, 3/2014., str. 527.

44 Zbog veoma brzog razvoja školstva, osnivanja viših škola i fakulteta, u kolovozu 1947. osnovan je Komitet za fakultete, više škole i znanstvene ustanove koji 1950. godine prerasta u Ministarstvo za znanost i kulturu. Reorganizacijom uprave 1951. godine ukinuto je i Ministarstvo prosvjete i Ministarstvo za znanost i kulturu, a uspostavljen je Savjet za prosvjetu, znanost i kulturu. Usp. Službeni list Bosne i Hercegovine, Sarajevo, 36/1947., str. 456; Službeni list Bosne i Hercegovine, Sarajevo, 19/1950., str. 326; Službeni list Bosne i Hercegovine, Sarajevo, 9/1951., str. 81-83.

45 Ivan Hofman, "Osnovno i srednje obrazovanje u Jugoslaviji 1945-1952.", u: B. Doknić - M. F. Petrović - I. Hofman (prir.), Kulturna politika Jugoslavije 19451952. Zbornik dokumenata, I., str. 71.

46 Isto, str. 72. 
gođavanje ovoga okvirnog zakona vlastitim prilikama. Kada je riječ o $\mathrm{BiH}$ valja naglasiti kako je još u ratnom razdoblju, s ciljem obrazovanja što većeg broja školskih obveznika u što kraćem roku, škola poprimila trostupanjski karakter (odvijala se u tri turnusa). Izuzetak su bile gradske škole koje su zadržale četverogodišnje obrazovanje, što jasno upućuje na neujednačenost sustava obrazovanja ne samo po trajanju školovanja nego i po nastavnim planovima i programima, organiziranju školske godine, razini stručnosti nastavnoga kadra i drugo. ${ }^{47}$ Kako bi se izbjegla ova neujednačenost, te potvrdila dosljednost u javnosti promoviranoga širenja osnovnoškolskoga obrazovanja, ZAVNOBiH je donio odluku o ukidanju trostupanjskoga školstva i prelasku na redovito četverogodišnje obrazovanje, počevši od 1. rujna 1945. Dakle, prema planovima Ministarstva prosvjete ovaj nepopularni ratni trend trebao je biti zaokružen prvom poslijeratnom školskom godinom koja se trebala završiti u tri mjeseca, odnosno u razdoblju od lipnja do kraja listopada $1945 .{ }^{48}$ Sljedeća redovita školska 1945./1946. godina započela je s dva mjeseca kašnjenja, tj. u studenome 1945., ali unatoč već spomenutom državnom Zakonu o obaveznim sedmogodišnjim školama u BiH radile su samo četverogodišnje osnovne škole. Za djecu koja su nakon četverogodišnjega obrazovanja odustajala od daljnjega školovanja u školskoj 1949./1950. godini s ciljem stjecanja šire opće naobrazbe pokrenute su produžene osnovne škole s V. i VI. razredom. ${ }^{49}$ Tek u ožujku 1947. donesen je Zakon o sedmogodišnjem osnovnom školovanju u $\mathrm{BiH}^{50}$ koji se počeo primjenjivati u školskoj 1947./1948. godini. Prve sedmogodišnje osnovne škole u Hercegovini otvorene su u Veličanima (Trebinjski srez) i Divinu (Bilećki srez). ${ }^{51}$ Sedmogodišnje obrazovanje provodilo se u dva oblika: otvaranjem viših razreda u osnovnim školama što je iziskivalo i stručno usavršavanje nastavnoga kadra, te objedinjavanjem četverogodišnje osnovne škole i niže gimnazije. Svakako valja napomenuti kako

47 Mitar Papić, Školstvo u Bosni i Hercegovini 1941-1955, Svjetlost, Sarajevo, 1981., str. 96.

48 Škole su počinjale s radom nakon osiguranja minimalnih uvjeta tako da su neke otvorene tek sredinom srpnja 1945. Usp. Isto, str. 96, 101.

49 U prvoj godini otvorene su samo dvije škole ovoga tipa koje je pohađalo 313 učenika, ali već sljedeće školske godine otvoreno je 100 produženih škola u kojima je bilo raspoređeno 27.995 učenika. Usp. ABiH, SPNK NR BiH, Kulturno-prosvjetni rad u Bosni i Hercegovini od oslobođenja do danas, kut. 17, br. 611/51., str. 7.

50 "Zakon o sedmogodišnjem osnovnom školovanju" u: Službeni listi NR Bosne i Hercegovine, Sarajevo, 13/1947., str. 136. Usp. "Zapisnik sa sjednice Vlade od 1. marta 1947. godine", u: R. Cvijović (prir.), Narodna Vlada Narodne Republike Bosne i Hercegovine 1945.-1948. Zapisnici, str. 94-96.

51 M. Papić, Školstvo u Bosni i Hercegovini 1941-1955, str. 107. 
je otvorena škola u Divinu bila prva sedmogodišnja škola na jugoslavenskom prostoru koja je imala samo starije razrede. ${ }^{52}$ Sedmogodišnje osnovno obrazovanje učenik je završavao polaganjem nižega tečajnog ispita nakon čega je mogao nastaviti školovanje u višoj gimnaziji ili nekoj srednjoj stručnoj školi..$^{53}$ Odluka o obveznom osnovnom obrazovanju u trajanju od osam godina donesena je na trećem Plenumu CK KPJ krajem 1949. godine, a u Bosni i Hercegovini počela je zaživljavati od školske 1949./1950. godine kad je bilo samo 18 osmogodišnjih škola, da bi početkom sljedeće školske godine njihov broj porastao na $51 .{ }^{54} \mathrm{Na}-$ ravno, ovaj proces prelaska prvo na sedmogodišnje, a kasnije i na osmogodišnje obrazovanje, kao jedinstvenu cjelinu nije tekao bez poteškoća, ne samo zbog neprilagođenih uvjeta nego i zbog uvriježenoga mišljenja da se opća naobrazba poslije završene četverogodišnje škole može stjecati jedino u nižim gimnazijama, tako da su one ugašene tek u školskoj 1957./1958. godini, a godinu dana kasnije prestaju s radom i niži razredi u punoj gimnaziji. ${ }^{55}$ Prema tomu možemo zaključiti kako je i vlada $\mathrm{BiH}$ odnosno Ministarstvo prosvjete uglavnom pratilo proces reorganiziranja obrazovnoga sustava koji se odvijao u skladu s naputcima državne vlasti. Istina, neki su zakoni realizirani sa zakašnjenjem u odnosu na ostale dijelove države što uopće ne začuđuje s obzirom na startnu poslijeratnu poziciju opterećenu ne samo ratnim razaranjima nego i veoma visokim stupnjem nepismenosti i poprilično siromašnom materijalnom i kadrovskom osnovom.

\subsubsection{Izgradnja školske mreže}

Jedan od osnovnih problema koje je u samom startu opterećivalo Ministarstvo prosvjete bio je nedostatak školskoga prostora. Naime, prema procjenama resornoga Ministarstva ni prijeratna školska mreža, s obzirom na broj škola ${ }^{56}$ i njihovu lociranost uglavnom u gradskim i prigradskim naseljima, nije mogla odgovoriti postavljenom zahtjevu "dostu-

52 Isto, (bilj. 177).

53 Isto, str. 107, 110; I. Hofman, "Osnovno i srednje obrazovanje u Jugoslaviji 19451952.", str. 72.

$54 \mathrm{ABiH}, \mathrm{SPNK}$ NR BiH, Kulturno-prosvjetni rad u Bosni i Hercegovini od oslobođenja do danas, kut. 17, br. 611/51., str. 7.

55 M. Papić, Školstvo u Bosni i Hercegovini 1941-1955, str. 110-111.

56 Prema podatcima Ministarstva prosvjete $\mathrm{BiH}$ u rujnu 1939. na području $\mathrm{BiH}$ radile su 1043 osnovne škole s 2505 odjeljenja. Usp. ABiH, MP NR BiH, Razvoj školstva u NR Bosni i Hercegovini u periodu obnove, kut. 228, br. 930/50., str. 1; ABiH, SPNK NR BiH, Kulturno-prosvjetni rad u Bosni i Hercegovini od oslobođenja do danas, kut. 17, br. 611/51., str. 7. 
pnosti škole širokim narodnim slojevima". Međutim, ondašnju stvarnu sliku dodatno su komplicirala i ratna razaranja u kojima je stradao velik broj školskih objekata, tako da je na području BiH krajem 1945. godine za rad osposobljeno tek 577 osnovnih škola s 1306 odjeljenja. ${ }^{57}$ U Hercegovini je od 247 prijeratnih osnovnih škola potpuno uništeno 148, teža oštećenja pretrpjelo je 56 škola, dok su 42 školske zgrade bile djelomično upotrebljive. ${ }^{58}$ Opredijeljenost za rješavanjem ove problematike vlada NR BiH iskazala je već u svojoj Deklaraciji od 2. svibnja 1945. najavljujući kako "će posvetiti veliku brigu prosvjećivanju naroda, rukovodeći se načelom da je školsko vaspitanje djece i omladine isključivo pravo države". ${ }^{59}$ Upravo na ovim postavkama krenulo se i u proces rješavanja oskudne školske infrastrukture. Ministarstvo prosvjete, na temelju zaključka Predsjedništva NS za $\mathrm{BiH}$, a prema preporuci Ministarstva prosvjete DFJ, uputilo je 14. svibnja 1945. dopis Oblasnom narodnom odboru za Hercegovinu u kojem ih obavještava da su sve privatne škole na području $\mathrm{BiH}$ ukinute, a njihov prostor, kako je naglašeno "radi nestašice školskih prostorija i inventara, prosvjetne narodne vlasti mogu iskoristiti". ${ }^{60} \mathrm{Da}$ se odmah pristupilo provedbi ovih naputaka potvrđuju izvješća Sreskoga narodnog odbora Mostar i Gradskoga narodnog odbora Mostar od 8. i 10. studenoga 1945. iz kojih je uočljivo da je od 20 narodnih škola koliko ih je u to vrijeme djelovalo na ovome području njih 11 smješteno u privatnim prostorijama. U napomeni ovoga dokumenta stoji kako većina privatnih i državnih školskih zgrada nema stakala na prozorima, te da privatne školske zgrade ne zadovoljavaju osnovne pedagoške i higijenske zahtjeve. ${ }^{61} \mathrm{U}$ kakvim uvjetima su radile škole u školskoj 1944./1945. godini najbolje će možda rasvijetliti citat iz jednoga arhivskog dokumenta u kojem piše: "Udžbenika nije bilo,

$57 \mathrm{ABiH}, \mathrm{MP}$ NR BiH, Razvoj školstva u NR Bosni i Hercegovini u periodu obnove, kut. 228, br. 930/50., str. 1 .

58 M. F. Petrović, "Polazne osnove za kulturno-prosvetni rad", str. 41 (bilj. 100).

59 R. Cvijović (prir.), Narodna Vlada Narodne Republike Bosne i Hercegovine 1945.1948. Zapisnici, str. 11.

60 ANHŽ/K, HONO OP, Privatne škole, kut. 500-2000/1945., br. 862/45., str. 1.

61 AHNŽ/K, HONO OP, Izvještaj o stanju škola, broju djece, učionica, odjeljenja i nastavnika, br. 2969/45., str. 1-3. Dodatni problem predstavljala je i činjenica da su neke škole useljavane u još uvijek dijelom nastanjene crkvene objekte, kao što je slučaj s I. osnovnom školom u Mostaru, pa je stoga vlast, više od skučenoga i mračnoga prostora, mučilo to što se u školskom prostoru osjeća "duh klera", jer kako ističu "časne sestre imaju na svakom spratu svoje prostorije, na svakom hodniku vjerske oznake, raspeće, slike" a dugo se u toj školi "povlačila čitanka N .D. H.". Usp. ANŽ/K, HONO OP, Izvještaj prosvjetnog rada u toku mjeseca aprila o. g., kut. 1200-2800/1946., br. 2463/46., str. 2. 
prikupljao se materijal iz starih čitanka, dječijih listova, prekucavao i umnožavao. Dječiji listovi 'Pionir' (Sarajevo) i 'Pioniri' (Beograd) uglavnom su služili kao čitanka u svim razredima. Pisaćeg pribora nije bilo dovoljno pa se u nekim školama pisalo na rubu novina, a u prvom razredu na pločama eternita. Mjesto pisaljke služio je ekser ili neki drugi oštri predmet. Školskih tabla takođe nije bilo. Pisalo se na neobojenoj dasci a negdje i na vratima učionice. $U$ nedostatku krede pisalo se kamenom (neka vrsta gline). Klupa nije takođe bilo. Djeca su od kuće donosila tronošce a negdje su na obične dvije klade postavili dasku i to je služilo za školsku klupu... Djeca su pisala na koljenima."62 Unatoč ovim teškim uvjetima nastava se odvijala, istina prema skraćenom nastavnom planu i programu koji je osmišljen u tijelima ZAVNOBiH-a kao trostupanjsko obrazovanje, tako da je ova školska godina završena sredinom listopada 1945. Već sljedeće školske godine, zahvaljujući prvenstveno delegiranim kreditima Ministarstva prosvjete, školski uvjeti su donekle popravljeni tako da je Prosvjetni odjel Hercegovačkoga okružnog narodnog odbora uspio osigurati i prve školske klupe s dva sjedišta, 33 školske ploče i 145 zemljopisnih karata, a preko knjižare "Iskra" u Mostaru i njezinih ispostava omogućena je nabavka udžbenika i školskoga pribora. ${ }^{63}$ Svakako najveći dio kredita bio je usmjeren na obnovu i izgradnju novih školskih zgrada, tako da je u razdoblju od 1945. do 1950. godine obnovljeno 615, a potpuno sagrađeno 289 školskih zgrada. ${ }^{64}$

Tabelarni prikaz porasta broja škola, učenika i učitelja u $\mathrm{BiH}$ za razdoblje 1945./1946.-1950./1951. ${ }^{65}$

\begin{tabular}{|l|l|l|l|}
\hline Školska godina & Broj škola & Broj učenika & Nastavni kadar \\
\hline $\mathbf{1 9 4 5 . / 1 9 4 6 .}$ & 718 & 120.722 & 1434 \\
\hline $\mathbf{1 9 4 6 . / 1 9 4 7 .}$ & 1036 & 206.032 & 1754 \\
\hline $\mathbf{1 9 4 7 . / 1 9 4 8 .}$ & 1295 & 257.625 & 2051 \\
\hline $\mathbf{1 9 4 8 . / 1 9 4 9 .}$ & 1376 & 267.967 & 2228 \\
\hline $\mathbf{1 9 4 9 . / 1 9 5 0 .}$ & 1471 & 277.912 & 2504 \\
\hline $\mathbf{1 9 5 0 . / 1 9 5 1 .}$ & 1847 & 279.621 & 3056 \\
\hline
\end{tabular}

$62 \mathrm{ABiH}, \mathrm{MP}$ NR BiH, Razvoj školstva u NR Bosni i Hercegovini u periodu obnove, kut. 228, br. 930/50., str. 1-2.

63 AHNŽ/K, HONO OP, Izvješće HONO upućeno Ministarstvu prosvjete, kut. 7000-8500/1946., br. 7405/46., str. 2.

$64 \mathrm{ABiH}, \mathrm{SPNK}$ NR BiH, Kulturno-prosvjetni rad u Bosni i Hercegovini od oslobođenja do danas, kut. 17, br. 611/51., str. 7.

65 Tabelarni prikaz izrađen je na temelju podataka Savjeta prosvjete nauke i kulture $\mathrm{BiH}$ iz 1951. godine. Usp. ABiH, SPNK NR BiH, Kulturno-prosvjetni rad u Bosni i Hercegovini od oslobođenja do danas, kut. 17, br. 611/51., str. 7. 
Ovaj trend širenja školske mreže pratila je i Hercegovina. Prema mjesečnom izvješću za rujan 1945. u Hercegovačkom okrugu već u prvoj poslijeratnoj školskoj godini otvoreno je 105 škola koje je pohađalo 15.422 učenika, raspoređenih u 233 odjeljenja u kojima je radilo 165 učitelja, ${ }^{66}$ da bi već u svibnju 1946. broj škola porastao na 143 s 343 odjeljenja, ${ }^{67}$ dok je u školskoj 1946./1947. godini bilo 177 škola s 456 odjeljenja, 211 nastavnika i 21.750 učenika. ${ }^{68}$

Tabelarni pregled porasta broja škola u Hercegovini u razdoblju od 1947. do $1951 .{ }^{69}$

\begin{tabular}{|l|l|l|l|l|l|}
\hline \multirow{2}{*}{ Srez } & \multicolumn{6}{l}{ Broj škola po godinama } \\
\cline { 2 - 6 } & $\mathbf{1 9 4 7}$ & $\mathbf{1 9 4 8 .}$ & $\mathbf{1 9 4 9 .}$ & $\mathbf{1 9 5 0 .}$ & $\mathbf{1 9 5 1 .}$ \\
\hline Mostar & 36 & 42 & 47 & 49 & 53 \\
\hline Grad Mostar & 4 & 4 & 4 & 5 & 6 \\
\hline Stolac & 12 & 15 & 18 & 20 & 20 \\
\hline Čapljina & 16 & 18 & 23 & 24 & 24 \\
\hline Nevesinje & 14 & 16 & 23 & 25 & 26 \\
\hline Gacko & 18 & 22 & 25 & 25 & 25 \\
\hline Bileća & 18 & 21 & 23 & 24 & 25 \\
\hline Konjic & 17 & 19 & 26 & 29 & 29 \\
\hline Livno & 21 & 24 & 27 & 27 & 27 \\
\hline Prozor & 8 & 10 & 12 & 14 & 15 \\
\hline Duvno & 18 & 21 & 26 & 26 & 26 \\
\hline Posušje & 8 & 10 & 12 & 12 & 12 \\
\hline Ljubuški & 17 & 21 & 25 & 26 & 28 \\
\hline Trebinje & 38 & 41 & 44 & 48 & 51 \\
\hline Ukupno: & $\mathbf{2 4 5}$ & $\mathbf{2 8 4}$ & $\mathbf{3 3 5}$ & $\mathbf{3 5 4}$ & $\mathbf{3 6 7}$ \\
\hline
\end{tabular}

Prema dostupnim arhivskim podatcima najveći broj ovih škola u hercegovačkom području bio je lociran u seoskim sredinama, što je nedvojbeno povezano sa zacrtanim ciljevima Prvog petogodišnjeg plana privred-

66 AHNŽ/K, HONO OP, Mjesečni izvještaj za septembar 1945., kut. 1-600/1945., br. 3610/45., str. 2.

67 HERCEGOVAČKI OKRUŽNI NARODNI ODBOR, Izvještaj o radu Izvršnog odbora..., str. 87.

68 AHNŽ/K, HONO OP, Izvješće HONO upućeno Ministarstvu prosvjete, kut. 7000-8500/1946., br. 7405/46., str. 1.

69 Tabelarni pregled rađen je prema podatcima HONO s napomenom da nedostaju podatci za Sirokobriješki srez. Usp. AHNŽ/K, HONO, Pokazatelji za osnovne škole po srezovima MONO-a, kut. 1945.-1946., Prosvjeta b.b. (razno), obrazac A. 
nog razvitka $\mathrm{BiH}$ koji je u oblasti školstva predviđao smanjivanje razlika između kulturno razvijenih i nerazvijenih područja bržim otvaranjem sedmogodišnjih škola upravo u industrijskim i seoskim područjima, uključivanje u obrazovni proces sve odrasle djece, te izgradnju prijeko potrebitih 3428 učionica za osnovne škole, budući da je većina otvorenih škola raspolagala tek $s$ jednom ili dvije učionice, što nije ni blizu zadovoljavalo normative potrebitoga korisnog učeničkog prostora. ${ }^{70}$

\subsubsection{Uloga škole u formiranju "nove svijesti"}

Sve ove pozitivne aktivnosti vlasti na razvoju školske mreže pod poznatom parolom "učiniti školu dostupnom svima", imale su zapravo i svoju političko-ideološku pozadinu jer zadatak škole nije bio samo dati opća znanja nego i stvoriti "nove ljude, građane socijalističkog društva, građane narodne države", odnosno, stvoriti i odgojiti "dobre patriote, svjesne radnike i dobre i čestite karaktere",71 što se trebalo postići, kako stoji u Privremenim uputama za rad narodnih škola, "odgajajući djecu u duhu Narodno-oslobodilačkog pokreta, čuvanja tekovina Narodnooslobodilačke borbe, duhu bratstva i jedinstva svih [naših] naroda, razvijajući u njima stvaralački kolektivni duh, samoprijegor, svjesnu disciplinu, upornost i oduševljenje za rad u cilju izgradnje [naše] državne zajednice-slobodne, demokratske i federativne Jugoslavije". $.22 \mathrm{U}$ skladu s ovako postavljenim zadatcima škole okosnicu u nastavi materinjega jezika, povijesti, pjevanja, pa i računa činili su sadržaji kojima su se veli-
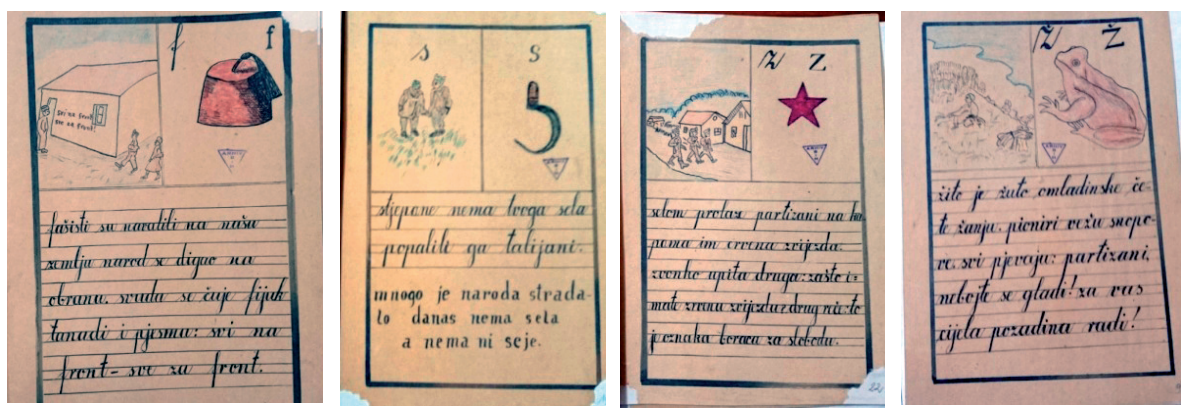

70 Prema podatcima Ministarstva prosvjete objavljenim tijekom školske 1952./1953. godine od postojećih 2097 osnovnih škola bila je čak 1171 škola sa samo jednom učionicom, $676 \mathrm{~s}$ dvije učionice, $115 \mathrm{~s}$ tri, $27 \mathrm{~s}$ četiri i tek $48 \mathrm{~s}$ pet i više učionica. Usp. M. PAPIĆ, Školstvo u Bosni i Hercegovini 1941-1955, str. 107, 124-125.

71 K. Spennjak, Javnost i propaganda. Narodna fronta u politici i kulturi Hrvatske 1945.-1952., str. 201.

$72 \mathrm{ABiH}, \mathrm{MP} \mathrm{NR} \mathrm{BiH}$, Privremene upute za rad narodnih škola prosvjetnog odjela Oblasnog narodnog odbora za Hercegovinu, kut. 193, 15/45., str. 15. 
čale partizanske ratne tekovine, što zorno potvrđuju izbori tema u obradi pojedinih slova iz bukvara izrađenoga 1945 . godine. ${ }^{73}$

Općenito, tekstovi objavljeni u bukvarima i čitankama za osnovnu školu u tematskom smislu odnosili su se na narodnooslobodilačku borbu, izgradnju zemlje, ideološki prilagođenu povijest jugoslavenskih naroda, uključujući i teme "bratskog" SSSR-a, te naravno neizostavno glorificiranje lika i djela Josipa Broza, što se savršeno uklapalo u postavljene ideološko-odgojne ciljeve nastavnoga procesa. ${ }^{74}$ Zanimljivo je kako se i nastava računa koristila za ideološki odgoj tražeći da se stečeno znanje o brojevima i mjerama poveže "sa životom tako da se zadaci uzimaju iz najbliže okoline: mjerenje učionice, voćnjaka, izračunavanja broja stanovnika u selu ili mjestu, broja mobilisanih i dobrovoljno javljenih u [našu] vojsku, omladinski i pionirski rad na skupljanju potreba za vojsku..."75 Iako su prve računice, prema ocjenama stručnih komisija, zadovoljavale u pogledu metoda obrade gradiva kritiziran je njihov odgojni aspekt jer su zadatci prema mišljenju vlastodržaca bili previše apolitični, odnosno "tuđi revolucionarnoj sadržini [naše] zemlje", tako da učenika nisu dovodila "u situaciju da se uzbudi, da se raduje, da se divi, da zavoli heroje rada, da mrzi štetočine, jednom riječju da zauzme jedan određen i pravilan stav",,76 a što je nedvojbeno bio osnovni zadatak škole kao institucije. Dakle, samo ono znanje koje prerasta u učeničko uvjerenje vodilo je postavljenom cilju, a to je "izgraditi svjesno, slobodno, borbeno i idejno čvrsto pokoljenje, naoružano naučnim pogledom na

$73 \mathrm{ABiH}, \mathrm{MP}$ NR BiH, Primjer bukvara iz 1945., kut. 197, br. 283/45.

74 "Elaborat o opštim prosvetnim prilikama u FNRJ (1945-1949)", u: B. DokNIĆ - M. F. Petrović - I. Hofman (prir.), Kulturna politika Jugoslavije 1945-1952. Zbornik dokumenata, I., dok. br. 161, str. 375. Jedan od zadataka nastave materinjega jezika prema nastavnom planu i programu iz 1948. godine bio je "da kod učenika razvija ljubav i odanost prema domovini i njenim narodima, osjećanje bratstva i jedinstva i oduševljenje za socijalističku izgradnju naše zemlje". Usp. Nastavni plan i program za osnovne škole Narodne Republike Bosne i Hercegovine, Svjetlost, Sarajevo, 1948., str. 9.

$75 \mathrm{ABiH}, \mathrm{MP}$ NR BiH, Privremene upute za rad narodnih škola prosvjetnog odjela Oblasnog narodnog odbora za Hercegovinu, kut. 193, 15/45., str. 17.

76 Unatoč činjenici da su zadatci svojim sadržajem prizivali slike "stvarnoga života" prikazujući aktivnost radništva, seljaštva, omladine, dostignuća NOB-a i stradanja od neprijateljske ruke, ipak prema procjenama "stručnjaka" nisu bili idejno-politički pravilno postavljeni. Tako primjerice ilustracija postolara $u$ jednoj računici, iako idejno prihvatljiva, ocjenjena je neprikladnom budući je postolar, prema mišljenju mjerodavnih službi, prikazan kao "najveći bednik na svetu, prosto prosjak". Usp. "Elaborat o opštim prosvetnim prilikama u FNRJ (1945-1949)", dok. br. 161, str. 379-380. 
svijet". ${ }^{77}$ Svakako vrlo važna uloga u formiranju svijesti budućih graditelja socijalističkoga društva, namijenjena je nastavi povijesti. Uvidom u nastavne planove i programe ideološka "uniformiranost" nastave povijesti uočava se već u postavljenim zadatcima ${ }^{78} \mathrm{u}$ kojima se nezaobilazno ističe uloga NOB-a kao zajedničkoga iskustva naroda Jugoslavije, te bratstvo i jedinstvo, i druge tekovine ostvarene zajedničke borbe. Međutim, da bi se od sa/znanja prešlo na promišljanje odnosno na način života prema željenoj matrici trebalo je, baš kao što je naglašeno u zadatcima nastave povijesti, potaknuti i emocionalnu reakciju učenika za određene osobe odnosno povijesne događaje, razvijanjem, s jedne strane ponosa i ljubavi prema "osloboditeljima", a s druge strane stalnim poticanjem mržnje prema mogućim i izmišljenim neprijateljima. Na važnost ovoga nastavnog cilja ukazao je i Vojislav Đurić u svome članku "O idejnosti nastave", retoričkim upitom "kakva korist od tih časova istorije, ako se na njima u đačkom srcu nije razbuktala mržnja prema napadaču i eksploatatorskoj klasi i ljubav prema radnim masama, divljenje njihovoj borbi, oduševljenje njihovom pobedom, plamena želja da se čuvaju i učvršćuju tekovine te borbe?"79 Inzistiranje na ovim zacrtanim ciljevima nastave povijesti, koji će ostati na snazi do kraja razmatranoga raz-

77 SnježAna Koren, Politika povijesti u Jugoslaviji (1945-1960). Komunistička partija Jugoslavije, nastava povijesti, historiografija, Srednja Europa, Zagreb, 2012., str. 120.

78 Nastavni planovi i programi za školsku 1945./1946. godinu izrađeni su na temelju saveznoga okvirnog programa i uz neznatne izmijene vrijedili su do školske 1947./1948. Prema ovim programima zadatak nastave povijesti je: "1. upoznavanje učenika sa prošlošću naših naroda i naše domovine Jugoslavije, 2. razvijanje ljubavi i odanosti prema domovini i njenim narodima, 3. učvršćivanje bratstva i jedinstva naših naroda i svih tekovina narodnooslobodilačke borbe, 4. odgoj učenika u nepomirljivoj mržnji prema neprijateljima domovine, prema svim onima koji rade na uništavanju tekovina naše narodno-oslobodilačke borbe". Usp. S. KoREN, Politika povijesti u Jugoslaviji..., str. 561. Prema nastavnom planu i programu za školsku 1948./1949. godinu zadatak nastave povijesti je: "da upozna učenike sa najvažnijim događajima iz prošlosti naših naroda i naše domovine Jugoslavije i da kroz to upoznavanje približi učenike pravilnom shvatanju istorije; da razvija ljubav i odanost prema domovini i njenim narodima; da, upoznavanjem borbe naših naroda u toku istorije protiv osvajača i ugnjetača, vaspitava učenike u duhu aktivne borbe za slobodu i nezavisnost svoje otadžbine; da učvršćuje i dalje razvija bratstvo i jedinstvo i ostale tekovine narodnooslobodilačke borbe; da razvija osjećanje ponosa svojom domovinom, njenom slavnom prošlošću i uspjesima u sadašnjosti, da razvija nepomirljivu mržnju prema neprijateljima otadžbine, prema svima onima koji rade protiv tekovina narodnooslobodilačke borbe; da razvija ljubav prema svim slobodoljubivim narodima". Usp. Nastavni plan i program za osnovne škole Narodne Republike Bosne i Hercegovine, str. 22.

79 Vojislav Đurić, "O idejnosti nastave", u: Savremena škola. Časopis za pedagoška pitanja, 1/1947., Beograd, str. 12; S. Koren, Politika povijesti u Jugoslaviji..., str. 122. 
doblja, potvrđuje i raspis Ministarstva prosvjete NR BiH upućen Prosvjetnom odjeljenju Okružnoga narodnog odbora u Mostaru, u kojem se traži, pod cijenu kažnjavanja, izbjegavanje svake površnosti i pukoga verbalizma u nastavi povijesti ocjenjujući takav pristup kao "neoprostiv propust u vaspitanju [naše] srednjoškolske omladine", jer kako je naglašeno, "dragocjeni materijal" NOB-a pravilnim tumačenjem nastavnika neupitno doprinosi "izgrađivanju lika [našeg] novog učenika. ${ }^{80}$ Pravilna obrada nobovske tematike i njezinih ostvarenja, kao najsvježiji pečat zajedništva jugoslavenskih naroda, trebala je poslužiti i u konstruiranju prošlosti kroz prizmu zajedničkoga povijesnog sjećanja. Složenost ovoga procesa u višenacionalnoj zajednici kakva je bila druga Jugoslavija rješavana je selektivnim sjećanjem, odnosno antonimijom sjećanje - zaborav, što nedvojbeno potvrđuje i Titov naputak prosvjetnim radnicima u kojem kaže: "U istoriji naših naroda ima velikim momenata i sve što je pozitivno u prošlosti naših naroda, treba da se usađuje u dušu mladih naraštaja. Nasuprot tome, bilo bi poželjno, i mi to moramo postići, da sve ono negativno, ono čime naši narodi ne mogu da se ponose, bude predano zaboravu..." ${ }^{81}$ Polazeći od ovih postavki središnje mjesto u nastavi povijesti pripalo je osobama i događajima koji su predstavljali simbole zbližavanja jugoslavenskih naroda, ukazujući na istovremenost njihova povijesnog razvoja od doseljenja do borbe za nacionalno oslobođenje od tuđinske vlasti, jer kako je Đilas tvrdio: "marksistička historija kao vaspitni predmet kod nas mora prikazivati stoljetnu borbu naroda Jugoslavije za slobodu, iznijeti na vidjelo nosioce te borbe - kako mase, kao osnovnog činioca, tako i pojedine velike ljude kao stjegonoše masa, njihovih težnji, nada i interesa. To je ono što iz prošlosti vezuje i mora da poveže narode Jugoslavije. Ali isto tako, ta istorija mora rasvijetliti i otkada je, preko kojih društvenih snaga i zašto, počela da se kod naroda Jugoslavije javlja težnja za zajedničkim državnim životom... Ona će otkriti da je samo radnička klasa bila u stanju da ostvari 'vjekovne' snove masa i pojedinih velikih ljudi za zbližavanjem i zajedničkim životom naših naroda". ${ }^{82}$ Dakle, ovo oživljavanje zajedničkoga sjećanja podrazumijevalo je i odricanje od nacionalnih posebnosti, a onda i od nacionalne povijesti jer se pod tim pojmom podrazumijevala, ne povijest pojedinih naroda, nego povijest naroda Jugoslavije. ${ }^{83}$ Tako Đilas

80 AHNŽ/K, HONO OP, Dopis Ministarstva prosvjete NR BiH br. 1066 od 30. siječnja 1946., kut. 1-600/1946., br. 584/46., str. 1.

81 Citirano prema: S. Koren, Politika povijesti u Jugoslaviji..., str. 133.

82 Milovan Đilas, "O nacionalnoj istoriji kao vaspitnom predmetu", u: Komunist, 1/1949., b. m., str. 70 .

83 Svaka nacionalna istorija kao vaspitni predmet mora biti istovremeno istorija svih naroda Jugoslavije, drukčije rečeno - u njoj mora biti zastupljena istorija svih nje- 
smatra da se primjerice nemanjićku državu ne može smatrati isključivo srpskom državom, niti se Nemanjiće može promatrati samo kao srpske vladare koji su progonili Makedonce i Crnogorce jer bi to, prema Đilasovu mišljenju, značilo s jedne strane upasti u srpski, makedonski ili pak crnogorski šovinizam, a s druge strane značilo bi predvidjeti činjenicu da tada nije bilo nacija, te da su se "srpski" feudalci jednako odnosili i prema srpskim kmetovima. Također, "hrvatske" i "slovenačke" seljačke bune u 16. stoljeću, prema Đilasovu naputku, treba promatrati kao istovremene bune i hrvatskih i slovenskih kmetova. Drugim riječima od povjesničara se očekivalo da pronađe zajedničke momente koji možda nisu vidljivi u samom startu, ali, kako je autor ustvrdio, "koji stvarno postoje - u borbi protiv zajedničkih reakcionarnih neprijatelja i u srodnosti razvitka pod sličnim ili vrlo sličnim uslovima". ${ }^{84}$ Dakle, kroz nastavu povijesti nastojalo se utjecati na oblikovanje slike prošlosti dajući joj integrativnu dimenziju, a koja je opet trebala poslužiti razumijevanju suvremenih procesa i izgradnji budućnosti u skladu s ideološkim postavkama vladajuće elite. Prema tomu ova kratka analiza obrazovnoga procesa, imajući u vidu njegov sadržajni i metodski karakter, neosporno potvrđuje tezu s početka poglavlja o školi kao instrumentu podrške i legitimacije uspostavljene poslijeratne komunističke vlasti.

\subsubsection{Učitelji "novoga doba"}

Ključa uloga u ideološkom formiranju budućih graditelja jugoslavenskoga društva namijenjena je učiteljskom kadru, jer prema Lenjinovu tumačenju, koje je postalo sastavnim dijelom jugoslavenskoga partijskog programa, zadatak nove pedagogije je "da poveže rad nastavnika sa zadacima socijalističke organizacije društva. To znači da nastavnik treba da sprema buduće aktivne graditelje komunističkog društva", odnosno, "delo vaspitanja i obrazovanja treba da se podredi zadacima konsolidacije novog društva". ${ }^{85}$ Imajući dakle, u vidu ove postavke ne začuđuje činjenica da je upravo ova društvena kategorija bila pod stalnom prismotrom kako partijskih tako i mjerodavnih državnih tijela vlasti. Iako su ministarstva prosvjete u suradnji s lokalnim tijelima vlasti ve-

zinih naroda i to tako da nijedan od njih ne smije ni u kom pogledu biti zapostavljen ili istaknut na račun drugoga. Svaka istorija naroda Jugoslavije mora vjerno prikazivati prošlost svih njezinih naroda. Usp. M. ĐilAs, "O nacionalnoj istoriji kao vaspitnom predmetu", str. 64 .

84 M. Đilas, "O nacionalnoj istoriji kao vaspitnom predmetu", str. 71-72; S. Koren, Politika povijesti u Jugoslaviji..., str. 133-134.

85 N. GončArov, "Politika i pedagogika", u: Savremena škola. Časopis za pedagoška pitanja, Beograd, 1/1948., str. 13. 
liku pozornost posvećivali "političkoj podobnosti" učitelja, problem nedostatka kadra zahtijevao je fleksibilniji odnos. Tako, već tijekom 1946. godine mjerodavna tijela, procjenjujući pozitivne pomake u političkim stajalištima jednoga dijela učitelja koji su nakon rata okvalificirani "nepodobnima", odobravaju njihov povratak u učiteljsku službu. ${ }^{86}$ Problem nedostatka učiteljskoga kadra posebice se osjetio u BiH. Razlog tomu svakako treba tražiti jednim dijelom i u njihovu prijeratnom deficitu, a onda i u ratnim stradanjima i otežanom radu učiteljskih škola tijekom ratnih zbivanja ${ }^{87}$ Prema tomu pitanje pomanjkanja učiteljskoga kadra u $\mathrm{BiH}$ u prvim poslijeratnim godinama postaje ne samo ključni kadrovski problem resornoga ministarstva, nego i politički problem podignut na općejugoslavensku razinu, čijem je rješenju trebalo doprinijeti odobreno otvaranje novih učiteljskih škola sa skraćenim trogodišnjim obrazovanjem, te organiziranje učiteljskih tečajeva u trajanju od minimalno 90 radnih dana do jedne školske godine, ovisno o potrebama na terenu..$^{88} \mathrm{U}$ rješavanje ove problematike 1947. godine uključila se i sindikalna središnjica prosvjetnih djelatnika Jugoslavije pozivajući učitelje na dobrovoljni odlazak u BiH. Iako je ovim planom predviđena privremena pomoć oko 250 učitelja, iz Hrvatske i Srbije javilo se po 79 učitelja, a iz Crne Gore 3 učitelja. ${ }^{89} \mathrm{~S}$ druge strane politika kontinuiranoga širenja školske mreže i nerazmjer u porastu broja učenika i učitelja imala je za posljedicu veliko opterećenje učitelja tako da je na jednoga učitelja prosječno dolazilo 150 do 200 učenika..$^{90} \mathrm{I}$ podatci iz Hercegovine potvrđuju ovakvo stanje, posebice kada je riječ o manjim sredinama. Samo ilustracije radi prema podatcima Hercegovačkoga okružnog odbora iz prve polovice 1946. godine razvidno je da je na području grada Mostara na jednog učitelja dolazilo 68 učenika dok je istovremeno na širokobriješkome području u prosjeku na jednoga učitelja dolazilo 149 učenika ${ }^{91}$ Naravno, ukoliko bi se ušlo u detaljnije analize sagledavajući broj učenika i učitelja na razini

86 K. SpeHnJak, Javnost i propaganda. Narodna fronta u politici i kulturi Hrvatske 1945.-1952., str. 198. Usp. "Ideološko-politička karakteristika učitelja, bivšeg ratnog zarobljenika", u: B. Doknić - M. F. Petrović - I. Hofman (prir.), Kulturna politika Jugoslavije 1945-1952. Zbornik dokumenata, I., dok. br. 62, str. 212.

87 M. PAPIć, Školstvo u Bosni i Hercegovini 1941-1955, str. 131.

88 "Elaborat o opštim prosvetnim prilikama u FNRJ (1945-1949)", dok. br. 161, str. 384. Tijekom 1945. i 1946. godine u BiH održano je ukupno 16 učiteljskih tečajeva. Usp. ABiH, MP NR BiH, Razvoj školstva u NR Bosni i Hercegovini u periodu obnove, kut. 228, br. 930/50., str. 3.

89 "Elaborat o opštim prosvetnim prilikama u FNRJ (1945-1949)", dok. br. 161, str. 384.

$90 \mathrm{ABiH}, \mathrm{MP}$ NR BiH, Razvoj školstva u NR Bosni i Hercegovini u periodu obnove, kut. 228, br. 930/50, str. 3 .

91 HERCEGOVAČKI OKRUŽNI NARODNI ODBOR, Izvještaj o radu Izvršnog odbora..., str. 87. 
pojedinih škola dolazi se i do podataka da su pojedini učitelji, kao što je slučaj u osnovnoj školi u Cimu, radili s preko dvjestotinjak učenika. ${ }^{92}$ Unatoč ovim opterećenjima, svjesni prevažanosti uloge učitelja u sveukupnome projektu izgradnje novoga društvenog poretka, od učitelja se u prvom redu očekivala nedvojbena političko-ideološka opredijeljenost, isključujući svaki oblik apolitičnosti, i duboki osjećaj za značaj i veličinu ostvarenih revolucionarnih tekovina "kako bi bili u stanju da tu veliku ljubav prenose na svoje vaspitanike i narod", jer u protivnom, ukoliko se nastavnik "ne saživi sa snažnim revolucionarnim, progresivnim promjenama koje su se desile, ne shvati [današnju] društvenu stvarnost - ne može biti nastavnik u pravom smislu riječi, niti učitelj i vaspitač mladih naraštaja". ${ }^{33}$ Prema tomu novi učitelji obogaćeni pročišćenim znanjem, utemeljenim na partijskoj teoriji istine i znanstvenosti, i oduševljenjem za rad trebali su biti potpuno u službi naroda. Naravno, od njih se očekivalo kontinuirano stručno usavršavanje, praćenje stručne literature i usvajanje iskustvenih rezultata kako bi, ne samo pratili "revolucionarne društvene promjene", nego bili i aktivni kreatori tih promjena jer njihov "časovnik ide 15 minuta naprijed". ${ }^{4}$ Problem nedostatka udžbenika, nedovoljne stručne osposobljenosti prosvjetnoga kadra, te neprihvatljive predratne pedagoške metode, barem djelomično trebale su ublažiti mjesečne učiteljske konferencije i seminari, koji su uglavnom organizirani tijekom školskih raspusta. Na seminarima i konferencijama osim stručnih predavanja redovito su obrađivane i razne političke teme kojima se željela ostvariti ideološko-politička pre/naobrazba učiteljskoga kadra. ${ }^{95}$ Jedan od primjera ovakvoga instruiranja prosvjetnih djelatnika predstavlja i manifestacija Prosvjetno pedagoške nedjelje koja je u Mostaru održana tri puta tijekom 1945. godine. Prema zapisniku s prvoga susreta (trajao od 7.-14. ožujka 1945.) koji je okupio 107 učitelja, najveći broj obrađenih tema odnosio se na tijek i postignuća NOB-a, ulogu masovnih organizacija, te kritiku prosvjetne politike u vrijeme prve Jugoslavije. Ova predavanja kao i odgovori na pitanja proizišla iz rasprave po navedenim temama ${ }^{96}$ trebala su poslužiti kao edukativne smjernice $\mathrm{u}$

92 AHNŽ/K, HONO OP, Izvještaj o stanju škola, broju djece, učionica, odjeljenja i nastavnika, br. 2969/45., str. 2.

93 "Narodni učitelji kao javni radnici", u: B. Doknić - M. F. Petrović - I. Hofman (prir.), Kulturna politika Jugoslavije 1945-1952. Zbornik dokumenata, I., dok. br. 125 , str. 287-288.

94 Isto, str. 287.

$95 \mathrm{ABiH}, \mathrm{MP}$ NR BiH, Razvoj školstva u NR Bosni i Hercegovini u periodu obnove, kut. 228, br. 930/50., str. 3 .

96 Osim vrlo "zanimljivih" pitanja kao što su "ulaze li u NOF i druge političke partije" ili pak "čija će vojska poslije oslobođenja ostati u zemlji", što jasno govori o 
budućem radu prosvjetara. ${ }^{97}$ Drugi, jednako zoran, primjer je učiteljska konferencija u Stocu (travanj 1945.) na kojoj su kroz političke referate učiteljima davane upute za tumačenje povijesnih uloga pojedinih osoba, pa je tako za Radića navedeno da je "po planu morao platiti glavom zato što je sa velikim uspjehom radio na podizanju i organizovanju seljaka i radnika i što su sva Radićeva stremljenja bila upućena prema bratskoj Sovjetskoj Rusiji, a ne prema Hitleru i Musoliniju".98 Za razliku od Radića njegov "nedostojni nasljednik", kako ga je predavač nazvao, Maček, okarakteriziran je kao narodni neprijatelj koji je osobno organizirao križare u borbi protiv NOP-a. Naravno, veličanje Tita, partije i značaja NOB-a bili su neizostavni dijelovi svih političkih predavanja, čijem glorificiranju su trebali doprinijeti i učitelji kako u nastavnim tako i izvannastavnim aktivnostima. Želeći jasno instruirate učitelje u njihovu budućem radu, dajući im do znanja "tko je gazda" na konferenciji je naglašeno kako "pravu političku propagandu ne vodi država nego Partija i stoga ova ima vrlo krupne i važne zadatke. Ona ima da razvija političku svijest kod naroda, da uvjerava, da organizuje da potpomaže narodnu vlast", te se stoga od prosvjetnih radnika koji djeluju među narodom očekuje ne samo podrška nego i poslušnost partijskim i državnim tijelima vlasti. ${ }^{99}$ Ako se ovim političkim pritiscima dodaju neuvjetnosti rada, stalna angažiranost na opismenjavanju stanovništva i ostale kulturnoprosvjetne aktivnosti, te nedovoljna skrb u materijalnom smislu, ne za-

neupućenosti pojedinih sudionika, raspravljalo se i o ulozi HSS i dr. Mačeka, o držanju nekih prosvjetnih djelatnika tijekom rata, te o "pojmu naroda" i nacionalnosti muslimana odnosno pojmu "Bošnjak". Objašnjenje na ovo pitanje dao je prof. Salih Nazečić ističući kako "pojam Bošnjak nije imao nacionalni karakter nego tek vjersko obilježje... Bosanskohercegovački narodi opredijelili su se prema vjerskoj pripadnosti nacionalno. U prvom redu Srbi i Hrvati, koji su imali svoje nacionalne centre. Muslimani su u nacionalnom pogledu zauzeli neodređen stav", pa prema Nezečiću, ni u novoj jugoslavenskoj državi ne može se tvrditi da su muslimani nacija "jer se gotovo ničim ne razlikuju od naroda s kojima u zajednici žive". Budući da je u novoj državnoj tvorevini nacionalno pitanje smatrano riješenim, Nezečić je svoje pojašnjavanje završio konstatacijom kako je bitno "da su ovakvim uređenjem [naše] države zagarantovani interesi muslimana kao i ostalih naroda". Usp. Mina Kujović, "Iz zapisnika o Pedagoškoj nedjelji, održanoj u Mostaru od 7. do 14. marta 1945. godine", u: Hercegovina, časopis za kulturno i historijsko naslijede, 9, Mostar, 1997., str. 246-247.

97 Isto, str. 244-245, 249.

98 AHNŽ/K, HONO OP, Zapisnik učiteljske konferencije za srez Stolac održane 19. i 20. aprila 1945., Politički referat, kut. 500-2000/1945., br. 694/1945., str. 2. Usp. V. Katz, "Nekoliko primjera ideološke upotrebe 'narodnog prosvjećivanja' u Hercegovini 1945.-1952.", str. 520.

99 AHNŽ/K, HONO OP, Zapisnik učiteljske konferencije za srez Stolac održane 19. i 20. aprila 1945., Politički referat, kut. 500-2000/1945., br. 694/1945., str. 3-4. Usp. 
čuđuje pad interesa za ovo zanimanje i sve brojnija pojava napuštanja struke prelaskom u razne državne službe. ${ }^{100}$

\subsubsection{Vjeronaučna pouka - od marginalizacije do potpunoga izbaci- vanja iz škole}

Status vjeronauka u poslijeratnom odgojno-obrazovnom procesu svakako je bio kamen spoticanja u crkveno-državnim odnosima. Imajući u vidu već istaknutu činjenicu kako su škole trebale biti ideološko-politički aparat državne vlasti u formiranju budućih "graditelja socijalističkog društva" ne začuđuje činjenica, da se unatoč ustavnim odredbama o slobodi vjere i vjerskoga naučavanja, već s preuzimanjem vlasti krenulo u borbu protiv utjecaja religije i vjerskih zajednica na odgojno-obrazovni sustav. Držeći se Marxove materijalističke filozofije i njegove teze o religiji kao iluzije ${ }^{101}$ koja stvara samo privid sreće i služi kao crkveni instrument za ostvarivanje svojih ciljeva, i Tito je još 1936. godine u članku "Komunisti i katolici" zaključio kako je "među ta dva nazora na svijet suprotnost [je] zaista nepomirljiva". ${ }^{102}$ Osim ovoga ateističkoga pogleda

V. Katz, "Nekoliko primjera ideološke upotrebe 'narodnog prosvjećivanja' u Hercegovini 1945.-1952.", str. 520-522.

100 "Elaborat o opštim prosvetnim prilikama u FNRJ (1945-1949)", dok. br. 161, str. 385. Usp. K. SPEHNJAK, Javnost i propaganda. Narodna fronta u politici i kulturi Hrvatske 1945.-1952., str. 200-201.

101 "Borba protiv religije je, dakle, posredno borba protiv onog svijeta, čija je duhovna aroma religija. Religijska bijeda je jednim dijelom izraz zbiljske bijede, a jednim dijelom protest protiv zbiljske bijede. Religija je uzdah potlačenog stvorenja, duša svijeta bez srca, kao što je i duh bezdušnih prilika. Ona je opijum naroda. Ukidanje religije kao iluzorne sreće naroda zahtjev je njegove stvarne sreće." Usp. Marx - Engels - Lenjin - Tito, O religiji, Ivan Cvitković (prir.), Veselin Masleša, Sarajevo, 1982., str. 41. Iako mnogi teolozi ističu kako definicija religije kao "opijum naroda" nije tipično marksistička, Lenjin naglašava kako je upravo ta izreka kamen temeljac sveukupnoga marksističkog pogleda na pitanje religije. Usp. Tomo Vereš, Filozofsko-teološki dijalog s Marxom. Misao i praksa u djelu Karla Marxa, Filozofsko-teološki institut Družbe Isusove, Zagreb, 1981., str. 119; IviCA ŠARAC, "Odnos Katoličke crkve u Hrvata prema komunizmu", u: Robert Jolić - Gabrijel Mioč - Marija Vukadin (prir.), Fra Ferdo Vlašić vizionar i patnik. Spomenica u povodu desete obljetnice smrti (1995.-2005.), Naša ognjišta, Tomislavgrad, 2005., str. 36 (bilj. br. 10-11).

102 M. FučEK, "Konsolidacija jugoslavenskoga socijalizma kroz ideološke aparate države", str. 523. Tijekom rata iz taktičkih razloga dolazi do tolerantnijega odnosa prema religiji i Crkvi, tako da su se u partizanskim jedinicama slavili i vjerski blagdani, a osim vjernika u NOB i njegova tijela uključio se i jedan broj svećenika. Usp. Radmila Radić, Verom protiv vere. Država i verske zajednice u Srbiji 1945-1953, Institut za noviju istoriju Srbije, Beograd, 1995., str. 101-111. 
na svijet i ideološkoga utjecaja SSSR-a, negativan stav nove vlasti prema vjerskim zajednicama, poglavito prema Katoličkoj crkvi, počivao je na povezanosti Crkve i nacionalizma, i tezama o njezinoj ulozi tijekom Drugoga svjetskog rata. ${ }^{103}$

Ograničavanje crkvenoga utjecaja na obrazovanje započelo je ukidanjem prihvatnih škola, ${ }^{104}$ među kojima su prednjačile one u vlasništvu Crkava, preko zakonskih uredbi o vjeronauku kao izbornom predmetu, pa do njegova potpuna uklanjanja iz državnih škola i izdvajanja teoloških fakulteta sa sveučilišta. Da je od samoga početka organiziranja školstva postojao interes za vjerskom poukom u školama potvrđuje i dopis Sreskog narodnog odbora u Mostaru od 7. svibnja 1945. u kojem je zatražena suglasnost Oblasnoga narodnog odbora za imenovanje vjeroučitelja u 15 osnovnih škola. Iz dopisa je razvidno kako je riječ o dva prijedloga, jedan koje su dostavile škole, te drugi koji je osmislio Prosvjetni odjel Sreskoga narodnog odbora predlažući za vjeroučitelje, uglavnom, učitelje odnosno učiteljice one vjeroispovijesti kojoj pripadaju školska djeca, uz obrazloženje kako je "moguće kontrolisati u školi rad učitelja lakše nego rad sveštenika". ${ }^{105}$ Kako bi se izbjegle ove nejasnoće u proceduri imenovanja vjeroučitelja, Ministarstvo prosvjete narodne vlade $\mathrm{BiH} 12$. svibnja 1945. donijelo je Privremena uputstva za izvođenje vjeronaučne nastave u kojima je prvom točkom naglašeno da se vjeronauk smatra izbornim predmetom, a odobrenje za rad, na prijedlog vjerskih vlasti, izdaju okružni narodni odbori. Prema ovome naputku, koji je ostao na snazi do listopada 1947., vjeronauk mogu predavati samo kvalificirani vjeroučitelji koji su završili odgovarajuće škole (bogoslovije, okružne medrese). ${ }^{106}$ Kakvim su političkim torturama od samih početaka vjeroučitelji bili izloženi potvrđuje i raspis Ministarstva prosvjete DFJ od 9. srpnja 1945. u kojem opominju pojedine prosvjetne vlasti zbog pritisaka na svećenike tražeći od njih da se "raščine", te naglašavaju da se svećenicima ne može zabraniti niti predavanje ostalih nastavnih predmeta "ako za to imaju potrebne kvalifikacije i ako prosvjetne vlasti pojedinih

103 Miroslav AkmadžA, Katolička crkva u Hrvatskoj i komunistički režim 1945.1966., Otokar Keršovani, Rijeka, 2004., str. 9; IvicA Lučić, "Komunistički progoni Katoličke crkve u Bosni i Hercegovini (1945.-1990.)", u: R. Jolić - G. Mioč - M. Vukadin (prir.), Fra Ferdo Vlašić - vizionar i patnik. Spomenica u povodu desete obljetnice smrti (1995.-2005.), Naša ognjišta, Tomislavgrad, 2005., str. 53.

104 ANHŽ/K, HONO OP, Privatne škole, kut. 500-2000/1945., br. 862/45., str. 1.

105 AHNŽ/K, HONO OP, Prijedlog za postavljanje vjeroučitelja u osnovnim školama, kut. 500-2000/1945., br. 768/45., str. 1-3.

$106 \mathrm{ABiH}$, Komisija za vjerska Pitanja (dalje: KVP), Pitanje vjeronaučne nastave kao fakultativnog predmeta, kut. 1, br. 72/46., str. 2-3. Naputak je u listopadu 1946. doživio izmjene kojima se detaljnije obrazlaže način financiranja vjeroučitelja. 
federalnih jedinica nađu za shodno da im to odobre". ${ }^{107}$ Nove, opširnije upute za održavanje vjerske nastave u osnovnim školama i gimnazijama donesene su 1. listopada 1947. kojima je propisano da se u osnovnim školama o vjeronaučnoj pouci učenika trebaju izjasniti roditelji, dok su se učenici gimnazije mogli samostalno izjašnjavati. Održavanje vjerske nastave vršilo se pod nadzorom školskih vlasti i izričito u školskom prostoru, nakon redovite nastave. Tjedna satnica, jedan sat za osnovne i dva sata za srednje škole, bila je prepuštena na volju ravnateljima škola, a ocjena iz ovoga predmeta nije upisivana u svjedodžbu. I dalje su dopuštenje za poučavanje u osnovnim školama izdavale mjerodavne institucije lokalne vlasti, a za gimnazije Ministarstvo prosvjete, s napomenom da to ne može biti osoba koja je "lišena časnih prava". ${ }^{108}$ Kao što se vidi iz sadržaja i ovaj naputak išao je na štetu vjerskih zajednica, odnosno kreiran je tako da s jedne strane oteža proceduru izjašnjavanja djece za vjersku pouku, a s druge strane omogućavao je strogi školski nadzor nad vjerskom nastavom. U borbi protiv utjecaja Crkve, odnosno religije uopće, vlast je svesrdno računala na potporu školskoga kadra pa ih je $\mathrm{u}$ tom smislu nastojala "kontrolirati" bilo pridobivanjem u političkom smislu, bilo opomenama, prijetnjama ili pak otpuštanjima s posla. ${ }^{109}$ Posebna uloga bila je namijenjena nastavnicima povijesti i prirodnih znanosti od koji se očekivalo da kroz nastavu znanstvenim argumentacijama pridonesu borbi protiv religioznoga pogleda na svijet, a njihov učinak, prema mišljenju prosvjetnoga inspektora Ivana Lerika, smatrao se uspješnim "tek onda ako se pokažu i praktični rezultati, kao na pr. mnogo manje posećivanje časova vjeronauke"110

Ova postupna uskraćivanja prava vezanih za vjersku pouku vodila su jasnome cilju - potpunom ukidanju vjerske nastave kako u školskim

107 AHNŽ/K, HONO OP, Dopis Ministarstva prosvjete DFJ br. 2288 preko Ministarstva prosvjete narodne vlade BiH, kut. 500-2000/1945., br. 1757/45., str. 1 .

108 Prema Uputstvu plaćanje vjeroučitelja bila je obveza roditelja čija djeca pohađaju vjeronaučnu nastavu. Usp. ABiH, KVP, Uputstvo za održavanje vjerske nastave u narodnim osnovnim školama i gimnazijama, kut. 1, br. 176/47., str. 1.

109 U pismu koje je nadbiskup Ujčić uputio Josipu Brozu 1956. godine ukazano je na raskorake sa zakonskim i ustavnim propisima kada je riječ o slobodi vjeroispovijesti i slobodi savjesti, što Nadbiskup potkrepljuje i nekim primjerima kao što je uručivanje otkaza nastavnici Alojziji Ulman uz obrazloženje kako "nije usvojila materijalističko shvatanje na svijet", ili pak isključenje iz nastavničkoga udruženja Hele Žnidarčić, nastavnice u Bosanskom Brodu, što je obrazloženo "njenim ispoljavanjem verskih osećanja". Usp. ABiH, KVP, Pismo nadbiskupa Ujčića Maršalu Jugoslavije Josipu Brozu Titu, kut. 5, br. 122/57., str. 1.

110 I. Hofman, "Osnovno i srednje obrazovanje u Jugoslaviji 1945-1952.", str. 86 (bilj. br. 254). Usp. K. SpehnjaK, Javnost i propaganda. Narodna fronta u politici i kulturi Hrvatske 1945.-1952., str. 192 (bilj. br. 70). 
tako i crkvenim objektima. Zbog takve politike režima u više navrata reagirala su vodstva vjerskih zajednica. ${ }^{111}$ Katolički biskupi sa zasjedanja u Ljubljani 1947. godine uputili su predstavku Predsjedništvu vlade FNRJ kojom upozoravaju na sve češće kršenje ustavnih prava Crkve u njezinu sudjelovanju pri odgoju mladoga naraštaja, dok se $s$ druge strane, kako su ustvrdili, učenicima nameću ideologizirane teorije koje "prikazuju svjetsku i crkvenu povijest na način, koji u mladim dušama mora izazvati pobudu protiv religije". ${ }^{112}$ Međutim, stav komunističke vlasti bio je neumoljiv, pa stoga vjerskim zajednicama nije preostalo drugo nego se uklopiti u pravila nove vlasti. Na zamolbe vjerskih zajednica u ljubuškom srezu, Oblasni narodni odbor za Hercegovinu dostavio je 5. srpnja 1945. suglasnost za katoličke vjeroučitelje u 12 škola i dva vjeroučitelja za djecu islamske vjeroispovijesti. ${ }^{13}$ Prema raspoloživoj arhivskoj građi može se zaključiti da je najviše interesa za vjersku pouku pokazivala Katolička crkva, što potvrđuju i dopisi Biskupskoga ordinarijata u Mostaru upućeni mjerodavnim tijelima vlasti sa zahtjevom za imenovanjem vjeroučitelja kako za osnovne škole tako i za gimnazije. ${ }^{114} \mathrm{Na}$ popuštanje nekih vjerskih zajednica očito utjecao je, ne samo proceduralni postupak nego i problem plaćanja vjeroučitelja kao i

111 Arhijerejski sinod Pravoslavne crkve svojom predstavkom od 4. travnja 1945. tražio je od Ministarstva prosvjete DFJ da se uvjeti za održavanje vjerske nastave vrate na predratno stanje. Usp. M. F. Petrović, "Polazne osnove za kulturnoprosvetni rad", str. 56. Opširnije o pisanim predstavkama koje su upućivali katolički biskupi po pitanju vjerske pouke u školama opominjući vlast na povrjede zakona može se pronaći u: M. AKmADžA, Katolička crkva u Hrvatskoj $i$ komunistički režim 1945.-1966., str. 84-92; Miroslav AKMADžA, Dopisivanje i razgovori između predstavnika Katoličke crkve i komunističke državne vlasti u Jugoslaviji 1945.-1952, sv. I., Društvo za povjesnicu Zagrebačke nadbiskupije "Tkalčić" Zagreb - Hrvatski institut za povijest, podružnica za povijest Slavonije, Srijema i Baranje, Slavonski Brod - Zagreb, 2008., str. 328-370; NADA Kisıć-Kolanović, "Pisma zagrebačkog nadbiskupa Alojzija Stepinca predsjedniku narodne vlade Hrvatske Vladimiru Bakariću 1945.", u: Croatica christiana periodica, 29, Zagreb, 1992., str. 148-149, 160-164.

112 Hrvatski državni arhiv (dalje: HDA), Osobni fond Svetozara Rittiga (dalje: OF Svetozar Rittig), Predstavka katoličkih biskupa Jugoslavije Predsjedništvu vlade FNRJ - prijepis, fond 816, kut. 7, str. 1.

113 AHNŽ/K, HONO OP, Sreskom narodnom odboru Ljubuški - Odobrenje za predavanje vjeronauka, kut. 500-2000/1945., br. 1088/45., str. 1.

114 Vidjeti u: AHNŽ/K, HONO OP, dokumenti br. 3529/46.; 7696/46.; 7689/46.; 6836/46.; 7696/46. Arhiv Biskupskoga ordinarijata u Mostaru (dalje: ABOM): Vjeroučitelji na osnovnim školama u Mostarskom srezu, br. 602/48., str. 1; ABOM, Vjeroučitelj na osnovnim školama u gradu Mostaru, br. 603/48., str. 1; ABOM, Vjeroučitelji u osnovnim školama konjičkog sreza, br. 606/48., str. 1. 
"strah da se ne zamere vlasti". ${ }^{115}$ Unatoč pojavama uskraćivanja političke suglasnosti za pojedine vjeroučitelje ${ }^{116}$ čini se kako je proces imenovanja vjeroučitelja ipak, tekao puno jednostavnije u prvim poslijeratnim godinama, dok se od 1948. godine raznim administrativnim procesima i odlaganjem crkvenih zahtjeva u "ladice zaborava" ovaj proces nastojao usporiti, odnosno izbjeći. Vjerojatno su ova pravila primijenjena i na zamolbu biskupskoga delegata Mostarsko-duvanjske biskupije, don Andrije Majića, koji je, 28. kolovoza 1948., dakle prije početka nastave, uputio Sreskom narodnom odboru u Mostaru prijedlog vjeroučitelja za osnovne škole mostarskoga sreza, ${ }^{117}$ kao i zamolbu kojom se don Andrija obratio Ministarstvu prosvjete NR BiH, 30. kolovoza 1949., tražeći odobrenje za vjeroučitelje u gimnazijama u Mostaru, Ljubuškom, Čapljini, Širokom Brijegu i Konjicu, te za Učiteljsku školu u Mostaru. Odgovor je stigao kada je školska godina bila već u poodmaklom razdoblju, početkom siječnja 1950. Zamolba Ordinarijata bila je odbijena uz obrazloženje da "ne postoje uvjeti za održavanje nastave u pomenutim školama, jer prema izvještaju direktora tih škola, škole ne raspolažu sa slobodnim prostorom". ${ }^{118}$ To Ordinarijat nije obeshrabrilo. Don Andrija je bio upo-

115 "Elaborat o opštim prosvetnim prilikama u FNRJ (1945-1949)", dok. br. 161, str. 382.

116 Primjerice Sreski narodni odbor u Ljubinju dao je negativno mišljenje o don Stjepanu Batinoviću kao predloženom vjeroučitelju u Trebinju zbog, kako su procijenili, njegova izrazito neprijateljskoga stava prema državnoj vlasti, što je "dobilo [je] naručiti izražaj pri komentarisanju pastirskog pisma". Iako su u obrazloženju iznesene veoma ozbiljne optužbe, ipak na kraju priznaje se kako don Stjepanu "neprijateljsko djelovanje" nije dokazano niti u dva vođena sudska postupka, pa se stoga može zaključiti kako su navedene optužbe zapravo bile rezultat njihova straha od Batinovićeve dominacije u škole imajući u vidu stručnu osposobljenost školske učiteljice. Usp. AHNŽ/K, HONO, Don Stjepan Batinović, župnik Trebimlje, karakteristike, kut. 4200-5800/1946., br. 4228/46., str. 1.

117 ABOM, Vjeroučitelji na osnovnim školama u Mostarskom srezu, br. 602/48., str. 1. U ovome dokumentu predloženo je 13 svećenika za vjeronaučnu pouku u osnovnim školama mostarskoga sreza, izuzev grada Mostara. Posebnim dokumentom br. 603/48., predložen je fra Filip Sivrić kao vjeroučitelj za sve osnovne škole na području grada Mostara. Usp. ABOM, Vjeroučitelj na osnovnim školama u gradu Mostaru, br. 603/48., str. 1. Prema trećem dokumentu adresiranom na Sreski narodni odbor Konjic, predložena su trojica svećenika za pet osnovnih škola konjičkoga sreza. Usp. ABOM, Vjeroučitelji u osnovnim školama konjičkoga sreza, br. 606/48., str. 1; Usp. Tомо Vuкšıć, Confessores fidei. Čule, Čekada, Majić, Nuić, Perić, Crkva na kamenu, Mostar, 2000., str. 183.

118 ABOM, Nastava vjeronauka u nekim školama, br. 12/50., str. 1; T . Vukšıć, Confessores fidei. Čule, Čekada, Majić, Nuić, Perić, str. 183; Božo GolužA, "Katolička Crkva u Hercegovini u vrijeme komunističke Jugoslavije", u: ŽELJKo MaJIĆ (prir.), Izvedi narod moj, o Gospodine! Život i djelo mons. Mate Nuića, Biskupski ordinarijat, Mostar, 2003., str. 37 (bilj. 17). 
ran u svojim nastojanjima da ostvari zakonska prava koje je Katoličkoj crkvi propisao Ustav i doneseni zakonski akti, pa se po istom pitanju nastavio obraćati Ministarstvu za prosvjetu u kolovozu 1951., a potom i 1952. godine. ${ }^{119}$ Odgovor s ove instance nije stizao, ali je 6. listopada 1952. u Ordinarijatu zaprimljen dopis Odsjeka za prosvjetu i kulturu čapljinskoga sreza u kojem veoma kratko službenim jezikom izvješćuju Ordinarijat kako ne mogu udovoljiti njihovu zahtjevu za održavanjem vjerske nastave u osnovnim školama jer "prema raspisu bivšeg Ministarstva prosvjete", kako je naznačeno, "niste zadovoljili istom"..120 Odugovlačenja mjerodavnih tijela vlasti s odgovorima odnosno dozvolama potrebnim za rad vjeroučitelja postala su ustaljena praksa u razdoblju nakon 1948. godine o čemu svjedoče i izvješća Agitpropa CK SKH u kojem se jasno instruira da se na zamolbe Crkve odgovara "namjerno s velikim zakašnjenjem", jer, kako je naglašeno, "ni jedan svećenik dok ne primi rješenje ne može da vrši vjersku nastavu", pa stoga "većina ovakvih predmeta ostavi se da zastari ili se riješi telefonski, a vrlo rijetko pismeno"."121 Kakav su učinak imale poduzete mjere potvrđuju i podatci autora "Elaborata o prosvjetnim prilikama u FNRJ", prema kojima se do 1949. godine vjeronauk pohađao samo u 45 bosanskohercegovačkih osnovnih škola (od mogućih 1400), dok su istovremeno od srednjih škola vjersku pouku imale samo medresa u Sarajevu i franjevačka gimnazija u Visokom. Drugim riječima vjeronauk je pohađalo samo 10.418 učenika ${ }^{122}$ među kojima su prednjačili katolici (5354 učenika), zatim muslimani (3646) i pravoslavni (1468 učenika). S obzirom na navedene podatke autor elaborata s pravom zaključuje kako u BiH "verska nastava ne predstavlja ozbiljan problem", ali ipak naglašava kako unatoč zabilježenom padu broja učenika koji odlaze u crkvu u nekim tradicionalno vjerskim hercegovačkim mjestima (Široki Brijeg, Ljubuški, Livno) nisu "iskorenjena verska ubeđenja", pa stoga preporuča ustrajnost u borbi "za iskorenjivanje tih ubeđenja i raznih drugih oblika mistike". ${ }^{23}$

119 Usp. ABiH, SPNK NR BiH, Postavljenje i odobrenje vjeroučiteljima na srednjim školama, kut. 29, br. 11536/52., str. 1.

120 ABOM, Vjerska nastava u osnovnim školama, br. 422/52., str. 1. Dokument nadnevka 2. listopada 1952., potpisao je sekretar Odsjeka Veljko Mandrapa.

121 K. SPEHNJAK, Javnost i propaganda. Narodna fronta u politici i kulturi Hrvatske 1945.-1952., str. 195; Tomislav Vuković, "Intervencija vjerske komisije", u: Glas Koncila, Zagreb, 17/2006., str. 25.

122 Ako se uzme u obzir da je u to vrijeme u BiH bilo oko 268.000 učenika, znači da je njih samo $4 \%$ pohađalo vjersku pouku. Usp. I. Hofman, "Osnovno i srednje obrazovanje u Jugoslaviji 1945-1952.", str. 86-87.

123 "Elaborat o opštim prosvetnim prilikama u FNRJ (1945-1949)", dok. br. 161, str. 380-381. 
Jedan od oblika ustrajnosti u toj borbi bile su i nove zakonske regulative o proslavama vjerskih blagdana. Prema uredbi Ministarstva prosvjete NR BiH školski praznici za katolike i pravoslavne osim državnih praznika uključivali su: "Badnji dan, dva dana Božića, Bogojavljenje, Veliki petak, Velika subota, prvi i drugi dan Uskrsa, prvi i drugi dan Duhova i Spasovdan", te dodatno za pravoslavne dan Sv. Save, Đurđevdan i dan Krsne slave, a za katolike Tijelovo i Svi Sveti. Za muslimane, prema ovoj uredbi praznikovali su se: tri dana Ramazanskoga bajrama, tri dana Kurban bajrama i jedan dan Mevluda. ${ }^{124}$ Već 1947. godine vjerski blagdani svedeni su na minimum, pa su neradni dani bili jedino Božić i Uskrs, a 22. prosinca 1948. Vlada FNRJ povjerljivim raspisom signalizirala je nižim tijelima da se Božić kao školski praznik više ne priznaje, što je službeno i potvrđeno 1949. godine kada su iz popisa školskih praznika izbačeni svi vjerski blagdani. ${ }^{125}$ Prema Zakonu o narodnim školama koji je usvojen 26. studenoga 1951., škola je dobila status društvene institucije čiji su djelatnici postali javni društveni radnici sa zadatkom odgoja djece u socijalističkom duhu, a već početkom 1952. godine sukladno Brozovoj teoriji o dosljednoj odvojenosti Crkve od države, vjeronauk je potpuno izbačen iz državnih škola. ${ }^{126}$ Ova odluka popraćena je propagandom o školi kao odgojno-obrazovnoj instituciji koja mora počivati na znanstvenim osnovama, dok je religioznost tumačena kao osobna stvar pojedinca, koju su, kako se može zaključiti, "društveno prosvjetni radnici" mogli narušavati. O torturama koje su kroza školski sustav, uz blagoslov režimske vlasti, proživljavali neki religiozni učenici i u razdoblju nakon izbacivanja vjeronauka iz škole svjedoči žalba koju je župnik u Potocima, don Cvitan Radišić, uputio na adresu Biroa za predstavke i pritužbe pri Izvršnom vijeću NR BiH. U ovoj predstavci don Cvitan upozorava na postupke Viktora Rogulje, nekadašnjega ravnatelja a tadašnjega učitelja u osnovnoj školi u Potocima, koji, prema don Cvitanovim navodima, "zastrašivanjem, prijetnjama, moralnim i fizičkim proganjanjem djece" ugrožava njihovo pravo na slobodno ispo-

124 AHNŽ/K, HONO OP, Rješenje Ministarstva prosvjete NR BiH o školskim praznicima, kut. 8000-9500/1946., br. 9178/46., str. 1.

125 Školski praznici 1949. godine bili su: 1. i 2. svibanj, 29. i 30. studeni i 1. i 2. siječanj. Učenici katoličke vjeroispovijesti mogli su izostati s nastave 25. prosinca i 1. studenoga, a pravoslavni 7. siječnja i na dan krsne slave. Usp. R. Radić, Verom protiv vere. Država i verske zajednice u Srbiji 1945-1953, str. 190; M. F. Petrović, "Polazne osnove za kulturno-prosvetni rad", str. 56; M. АкмADžA, Katolička crkva u Hrvatskoj i komunistički režim 1945.-1966., str. 93.

126 K. Spennjak, Javnost i propaganda. Narodna fronta u politici i kulturi Hrvatske 1945.-1952., str. 196-197; M. AкмADžA, Katolička crkva u Hrvatskoj i komunistički režim 1945.-1966., str. 95. 
vijedanje vjere i vršenje vjerskih obreda. U svojoj pritužbi don Cvitan navodi više primjera protuzakonitoga postupanja učitelja Rogulje ističući kako je "u školi pred pravoslavnom i muslimanskom djecom izrugivao katolički Oče naš, ispovijed i pričest i katoličkog svećenika... Godine 1953. ili 54. /ako bude potrebno doći će otac i sve će detalje potanko iznijeti/ Rogulja se prijeti jednom djetetu, da nedjeljom ne ide u crkvu na službu božiju. No ne pomaže: dijete ide na Misu. Prijeti se ocu djeteta. - Dijete i dalje ide na Misu - izvršava prijetnju: dijete - nakon toga što je prošlo na koncu prethodne šk. godine! - i nakon toga što je čitav mjesec dana išlo u slijedeći razred!: vraća u prijašnji pozitivno završeni razred /čini mi se iz trećeg u drugi/. Takovih i sličnih slučajeva bilo je godina 1951., 52., 53., 54., 55. i 56. više". ${ }^{127} \mathrm{Na}$ kraju don Cvitan poziva mjerodavna tijela da se po iznesenom svestrano i temeljito informiraju u Bijelome Polju, ali ne isključivo kod onih koji će navedenoga učitelja iz nekih razloga zaštiti, kako bi se uvjerili u stvarno stanje ili će u protivnom biti prisiljen poduzeti pravne korake. ${ }^{128} \mathrm{U}$ privitku ove pritužbe nalazi se odgovor Sekretarijata za prosvjetu i kulturu narodnoga odbora Mostar broj: 08/1-14997/1 od 11. listopada 1958., koji nakon što je saslušao jedinoga svjedoka - "optuženog" Viktora Rogulju zaključuje da je prozvani "uzoran učitelj i primjeren pedagog, za svoj rad je i nagrađivan i pohvaljivan. Pored rada u školi, jako je aktivan u vanškolskom radu, uživa veliki ugled među stanovništvom", pa je kao takav, što je izgleda vrlo bitno, "izabran i za narodnog odbornika Opštine Mostar u izbornoj jedinici Potoci, gdje i djeluje". ${ }^{29}$

$\mathrm{O}$ učincima ideološkoga pre/odgoja uza sve poduzete mjere vlasti unutar školskoga obrazovanja, a imajući u vidu namijenjene ciljeve i zadaću škole kao odgojno-obrazovne institucije, možda se mnogo toga može iščitati iz rezultata popisa stanovništva iz 1953. godine, kao posljednjega koji je sadržavao kategoriju vjerske pripadnosti, prema kojima se istina, $\mathrm{u} \mathrm{BiH}$ uočava trend pada pripadnika tri najbrojnije vjerske zajednice, dok se broj stanovnika "bez vjerske pripadnosti", tj. ateista ili agnostika

$127 \mathrm{ABiH}, \mathrm{KVP}$, Pritužba don Cvitana Radišića, župnika župe Potoci - Bijelo Polje, kut. 6, br. 202/58., str. 1 .

128 Isto, str. 2.

129 Iako je u svojoj izjavi Rogulja priznao da je do donošenja Zakona o vjerskim zajednicama prigovarao djeci zbog odlaska na vjeronauk, kako ističe "zato što sveštenik nije imao za to odobrenje" ili barem on kao ravnatelj nije bio upoznat s tim odobrenjem, mjerodavna tijela nisu smatrala potrebnim pozabaviti se detaljnije tim pitanjem. Za njih je vjerojatno zanimljiviji bio Roguljin podatak o don Cvitanovu bojkotu izlaska na izbore u prethodnom razdoblju. Usp. $\mathrm{ABiH}$, KVP, Pritužba don Cvitana Radišića, župnika župe Potoci - Bijelo Polje, kut. 6, br. 202/58., str. 5 . 
popeo na $10,3 \%,{ }^{130}$ ali taj postotak još uvijek je bio manji od jugoslavenskoga prosjeka (12,3\% na popisu 1953.). S druge strane prikaz stanja u Hercegovini možda ponajbolje oslikava izvješće Savezne komisije za vjerska pitanja iz 1959. godine, koja sa zabrinutošću konstatira rast vjerske aktivnosti, ${ }^{131}$ posebice u Hercegovini gdje je kako stoji "katolički kler uveo novinu u tome što vrši ponovno primanje u katoličku vjeru onih koji su se prilikom popisa stanovništva 1953. godine izjasnili da su 'bez vjere'. Na ovome poslu sveštenici su pokazali izrazitu aktivnost na području opštine Grude, Lištica i Ljubuški". Osim toga uvedena je i praksa održavanja izvanrednih misa za vjernike koji ne idu javno u crkvu, te tajno primanje sakramenata, a "tim obredima prisustvovali su, pa čak i kumovali i neki članovi SKJ u Čerinu, Rasnom i nekim drugim mjestima". ${ }^{132}$

130 Podatci popisa za 1953. godinu preuzeti su od Radmile Radić s ispravkom koja se odnosi na postotak osoba "bez vjerske pripadnosti" gdje stoji da se u $\mathrm{BiH}$ za ovu kategoriju izjasnilo čak 30,3 \% osoba, što je grješka pri izračunu. Ispravan podatak je $10,3 \%$. Naime, prema navedenim podatcima u $\mathrm{BiH}$ od ukupno 2,844.000 stanovnika pravoslavnih je bilo 998.000, katolika 609.000, muslimana 918.000, ostalih 26.000, a "bez vjerske pripadnosti" 293.000. Usp. R. RADIĆ, Verom protiv vere..., str. 115. Isti postotak (30,3\%) pozivajući se na ovu autoricu spominje i Zdenko Radelić. Usp. Z. Radelić, Hrvatska u Jugoslaviji 1945.-1991. Od zajedništva do razlaza, str. 123.

131 "Po župama se organiziraju 'Misije' koje posjećuje i po 3000 vjernika. Bilježi se velik broj krizmanika. U Vrhbosanskoj nadbiskupiji i Mostarskoj biskupiji 1958. godine krizmano je preko 10.000 djece, a tijekom 1959. godine biskup Čule je u pet župa (od 31 planirane) krizmao oko 750 djece uz nazočnost preko 3500 vjernika i 27 svećenika. Vjerska pouka vrlo je raširena i organizira se u svim hercegovačkim župama a pohađa je preko 10.000 djece i mladih." Usp. Arhiv Jugoslavije (dalje: AJ), SAVEZna Komisija Za vjerska Pitanja (dalje: SKVP), Stanje i odnosi s RKC u BiH, od 22. 6. 1959., fond 144, fasc. 40, br. 144-40-345, str. 6.

132 Isto. 


\section{Eduational policy in the service of social reform of education in Herzegovina (from 1945 to 1952)}

\section{Summary}

Immediately after the consolidation of government, the Communist Party, recognizing the importance of the education system as a socialization medium, began its transformation in which very important role was attributed to the formation of a new "socialist man". Adhering to the motto that "an illiterate person stands out of politics", a broad campaign of eradication of adult illiteracy was started, organizing different levels of courses, reading groups, folklore groups and other forms of amateur organizations, which was a responsibility of educational departments of National Committee. General national enlightenment contributed to the radio and film production of carefully selected films like "The Defense of Moscow", "Liberation of Czechoslovakia", whose viewing was controlled by national authorities. In fact, the entire education system was subordinated to the single objective of building a collective identity that was supposed to ensure the legitimacy of the current government based on its leading authority role in NOB (National Liberation War). School naturally served as an important ideological apparatus in the education reform, having in mind its key role of a mediator in the interpretation of social reality. Therefore, great attention was paid not only to building of a widespread school network, but also to personnel policy and curricula that were abundant with "national liberation" themes and glorification of the role and person of Josip Broz. A special function was planned for history teaching that was to serve in the construction of the past through the prism of common historical memory. The complexity of this process in a multinational community as was the second Yugoslavia/Herzegovina resolved in selective memory or the antonymy such as memory vs. oblivion. Besides, the goal of teaching was not just the acquisition of knowledge, but also the empathy of students for specific topics in order to turn their knowledge into a way of thinking and living. Therefore, since the task of school was to raise similar ideological followers of the existing government, with great distrust was looked at religious education which, in fact, represented the only worldview "opposition" within the strictly controlled school system. Despite many legal restrictions and the regime's torture, catechism still managed to survive the first years as 
an elective course up to 1952, when it was expelled from public schools on the grounds that religiosity was personal matter of an individual, and that the school as an educational institution must be based on scientific grounds.

Keywords: Communist Party, People's Committee of Herzegovinian district, Herzegovina, ideology, education, literacy, school, teacher, church, religious education. 